\title{
The growing season greenhouse gas balance of a continental tundra site in the Indigirka lowlands, NE Siberia
}

\author{
M. K. van der Molen ${ }^{1}$, J. van Huissteden ${ }^{1}$, F. J. W. Parmentier ${ }^{1}$, A. M. R. Petrescu ${ }^{1}$, A. J. Dolman ${ }^{1}$, T. C. Maximov ${ }^{2}$, \\ A. V. Kononov ${ }^{2}$, S. V. Karsanaev ${ }^{2}$, and D. A. Suzdalov ${ }^{2}$ \\ ${ }^{1}$ Department of Hydrology and Geo-Environmental Sciences, Faculty of Earth and Life Sciences, Vrije Universiteit \\ Amsterdam, De Boelelaan 1085, 1081 HV Amsterdam, The Netherlands \\ ${ }^{2}$ Institute of Biological Problems of the Cryolithozone, Russian Academy of Sciences, Siberian Division, 41, Lenin Prospekt, \\ Yakutsk, The Republic of Sakha (Yakutia), 677980, Russian Federation
}

Received: 13 July 2007 - Published in Biogeosciences Discuss.: 17 July 2007

Revised: 4 October 2007 - Accepted: 29 October 2007 - Published: 14 November 2007

\begin{abstract}
Carbon dioxide and methane fluxes were measured at a tundra site near Chokurdakh, in the lowlands of the Indigirka river in north-east Siberia. This site is one of the few stations on Russian tundra and it is different from most other tundra flux stations in its continentality. A suite of methods was applied to determine the fluxes of NEE, GPP, $R_{\text {eco }}$ and methane, including eddy covariance, chambers and leaf cuvettes. Net carbon dioxide fluxes were high compared with other tundra sites, with $\mathrm{NEE}=-92 \mathrm{~g} \mathrm{C} \mathrm{m}^{-2} \mathrm{yr}^{-1}$, which is composed of an $R_{\text {eco }}=+141 \mathrm{~g} \mathrm{C} \mathrm{m}^{-2} \mathrm{yr}^{-1}$ and $\mathrm{GPP}=-232 \mathrm{~g} \mathrm{C} \mathrm{m}^{-2} \mathrm{yr}^{-1}$. This large carbon dioxide sink may be explained by the continental climate, that is reflected in low winter soil temperatures $\left(-14^{\circ} \mathrm{C}\right)$, reducing the respiration rates, and short, relatively warm summers, stimulating high photosynthesis rates. Interannual variability in GPP was dominated by the frequency of light limitation $\left(R_{g}<200 \mathrm{~W} \mathrm{~m}^{-2}\right)$, whereas $R_{\text {eco }}$ depends most directly on soil temperature and time in the growing season, which serves as a proxy of the combined effects of active layer depth, leaf area index, soil moisture and substrate availability. The methane flux, in units of global warming poten-

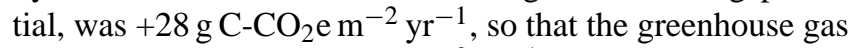
balance was $-64 \mathrm{~g} \mathrm{C}-\mathrm{CO}_{2} \mathrm{e} \mathrm{m}^{-2} \mathrm{yr}^{-1}$. Methane fluxes depended only slightly on soil temperature and were highly sensitive to hydrological conditions and vegetation composition.
\end{abstract}

\footnotetext{
Correspondence to: $\mathrm{M} . \mathrm{K}$. van der Molen (michiel.van.der.molen@falw.vu.nl)
}

\section{Introduction}

Tundra covers $8.7 \times 10^{6} \mathrm{~km}^{2}$ globally or $6 \%$ of the global land area (USGS land use/land cover classification, Anderson, 1976; van der Molen et al., 2007, ${ }^{1}$ ). Despite this modest area the role of tundra in the global carbon cycle is important: Tundra soils contain an estimated $200 \mathrm{Pg} \mathrm{C}$ or about $30 \%$ of the global soil carbon pool (Post et al., 1982, Schlesinger, 1999, Hobbie et al., 2000); Global warming is expected (IPCC, 2007) and observed (Serreze et al., 2000, Chapin et al., 2005, Hinzman et al., 2005) to be amplified in polar regions and Northern wetlands $\left(>60^{\circ} \mathrm{N}\right)$ emit $\sim 8 \%$ of the global natural methane flux (Cao et al., 1998). Being a strong greenhouse gas, increasing methane concentrations are responsible for $\sim 30 \%$ of the enhanced greenhouse effect (Forster et al., 2007). With an estimated carbon dioxide sink of $263 \mathrm{Tg} \mathrm{C} \mathrm{yr}^{-1}$ for Russian tundra areas, their role in the global carbon cycle is also substantial (van der Molen et al., $2007^{1}$ ). The stability of the tundra carbon pools is thus relevant to the global climate. To constrain the fluxes of carbon dioxide and methane, several experiments have been conducted in the past decades (cf. Chapin et al., 2000; McGuire et al., 2003). Major conclusions of these experiments are that the fluxes, particularly those of methane, show a high spatial variability due to heterogeneity in topography, vegetation and hydrology, even at the smallest scales of polygons and floodplains (van Huissteden et al., 2005; Kwon et al., 2006). Decomposition of soil carbon is sensitive to temperature changes and enhanced thawing (Zimov et al., 2006; Wagner et al., 2007), but growth of tundra ecosystems is

\footnotetext{
${ }^{1}$ van der Molen, M. K., Dolman, A. J., Belelli, L., et al.: The carbon balance of Boreal Eurasia consolidated with eddy covariance measurements, in review, 2007.
} 

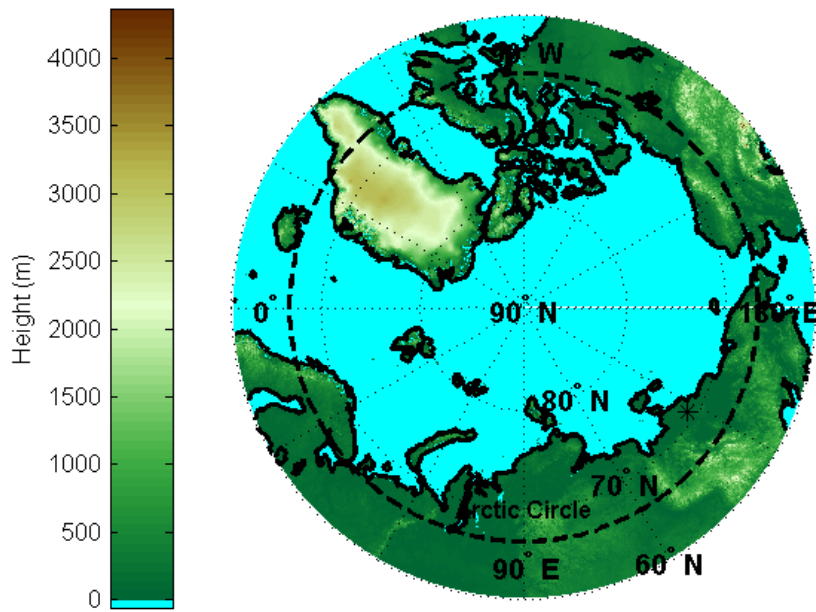

Fig. 1. Circum polar elevation map, the asterisk indicates the location of the site.

nitrogen limited, which would reduce the sensitivity to climate warming (Hobbie et al., 1998). The effect of climate warming in recent decades is already detected in the form of enhanced shrub growth and an advancement of the tree line (Jia et al., 2003; Lloyd et al., 2003; Esper et al., 2004).

The majority of the tundra field experiments were conducted on the North slope of Alaska and the Seward Peninsula in Alaska. The tundra areas in the Russian Federation, which comprise $45 \%$ of the total (van der Molen et al., $2007^{1}$ ), are much less studied: Heikinnen et al. (2002) report about an experiment in Vorkuta, European Russia, Wagner et al. (2003) about an experiment in the Lena Delta and Tsuzuyaki et al. (2001) and Corradi et al. (2005) about experiments in the floodplains of the Kolyma River near Cherskii. Christensen et al. (1995) performed methane flux measurements along a transect through Arctic Siberia via the Arctic Ocean. Other greenhouse gas flux studies were performed on tundra in Sweden (Christensen et al., 2004) and Greenland (Christensen et al., 2000; Friborg et al., 2000; Soegaard et al., 2000). However, climatic and environmental conditions vary considerably across the arctic, as a function of continentality (Sect. 2.1), distance to the northern treeline and the presence of mountain ranges (cf. Lynch et al., 2001).

Here we present the first combined observations of carbon dioxide and methane fluxes collected at a tundra site in the lowlands of the Indigirka river, near the village of Chokurdakh, in North East Siberia. At about $150 \mathrm{~km}$ from East Siberian Sea, the site is located roughly half way between the coast and the tree line. The nearest mountains are about $450 \mathrm{~km}$ to the South, making the latitudinal extend of the Indigirka lowlands some $600 \mathrm{~km}$, in comparison with $350 \mathrm{~km}$ between the Brooks Range and the Arctic Ocean in Alaska. As such, climate is more continental and less influenced by topography at this site than most other Arctic measuring sites. As $45 \%$ of the tundra area lies in the Rus-

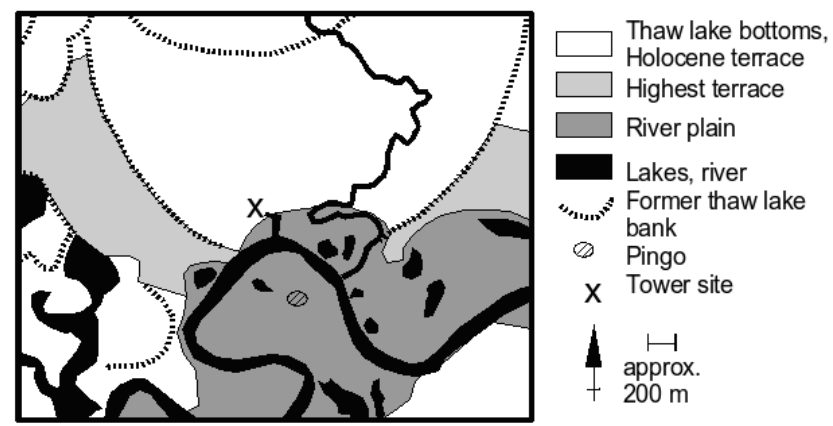

Fig. 2. Geomorphological map of the site, derived from field mapping and a satellite picture of the Kytalyk reserve on http://maps. google.com (http://maps.google.com/?1l=70.8275,147.4790\&spn= $0.1578,0.5905 \& \mathrm{t}=\mathrm{k})$.

sian Federation, where it is the largest land cover class after forest, this study provides data necessary to understand the carbon dioxide and methane balances of Boreal Eurasia and to put existing tundra field experiment in a circumpolar perspective.

Carbon dioxide fluxes were measured from 2003 to 2006, continuously during the summer using eddy covariance, complemented with chamber and leaf cuvette measurements of ecosystem respiration and photosynthesis rates. Methane flux measurements were carried out during intensive field experiments in the summers of 2004, 2005 and 2006. The objective of this study is to present the seasonal cycle of the carbon dioxide and methane fluxes, the resulting global warming potential, as well as the annual sums. For a better interpretation of the measurements, we perform and validate a partitioning of the net carbon dioxide fluxes into the components of ecosystem respiration and photosynthesis. We also use and validate the ORCHIDEE photosynthesis model and the PEATLAND-VU methane flux model to scale up the measurements in time and space.

\section{Site description and instrumentation}

\subsection{Site description}

The research site $\left(70^{\circ} 49^{\prime} 36.28^{\prime \prime} \mathrm{N}, 147^{\circ} 29^{\prime} 56.23^{\prime \prime} \mathrm{E}\right.$, $10 \mathrm{~m}$ a.m.s.l., Fig. 1) is located in the World Wildlife Fund Kytalyk (Crane) reserve, $28 \mathrm{~km}$ northwest of the village of Chokurdakh in the Republic of Sakha (Yakutia), Russian Federation. This puts the site roughly half way between the East Siberian Sea $(150 \mathrm{~km}$ to the North) and the transition zone between taiga and tundra. The site is on the bottom of a thermokarst lake, that was drained by intersection of the Berelekh river, a tributary of the Indigirka river (Fig. 2). 
Table 1. Basic climatology of the study site as observed at the weather station near the village of Chokurdakh (WMO station 21946 Chokurdakh) between 1999 and 2006. Snow depths at the field station are usually 60-80 cm. Precipitation is reported for 1994-1999.

\begin{tabular}{llrrrrrrrrrrrrr}
\hline & & Jan & Feb & March & April & May & June & July & Aug & Sep & Oct & Nov & $\begin{array}{r}\text { Dec } \\
\text { mean } \\
\text { total }\end{array}$ \\
\hline temperature & ${ }^{\circ} \mathrm{C}$ & -34.2 & -34 & -26.6 & -17.9 & -5.1 & 6.9 & 10.4 & 7.8 & 1.3 & -10.8 & -23.2 & -30.5 & -13 \\
precipitation & $\mathrm{mm}^{-1}$ & 9.7 & 9.7 & 9.4 & 6.0 & 13.5 & 26.5 & 22.6 & 35.2 & 28.1 & 21.8 & 18.6 & 10.5 & 211.7 \\
wind speed & $\mathrm{m} \mathrm{s}^{-1}$ & 3.3 & 3.6 & 3.3 & 3.7 & 4.4 & 4.8 & 4.6 & 4.0 & 3.9 & 3.6 & 3.4 & 3.9 & 3.9 \\
sun hours & hr day $^{-1}$ & 0.0 & 1.4 & 4.7 & 8.0 & 7.8 & 9.2 & 8.0 & 4.4 & 2.1 & 1.4 & 0.3 & 0.0 & 3.9 \\
frost days & days & 31 & 28 & 31 & 30 & 28.8 & 7.8 & 0.3 & 2.6 & 17.2 & 30.9 & 30 & 31 & 268.5 \\
snow days & days & 30.6 & 27.9 & 30.3 & 26.9 & 27.8 & 5.3 & 0 & 0 & 8.1 & 26.3 & 29.5 & 30.2 & 242.9 \\
show depth & cm & 26.5 & 31.6 & 37.1 & 38.3 & 30.8 & 1.5 & 0 & 0 & 2.7 & 10.1 & 20.6 & 23.8 & 18.6 \\
\hline
\end{tabular}

\subsubsection{Climatology}

A basic climatology is presented in Table 1. With a mean January temperatures of $-34.2^{\circ} \mathrm{C}$, the Chokurdakh site is colder than at other field sites e.g. near Scoresbysund (North East Greenland), Kiruna (North Sweden) and Vorkuta (East European Russia) $\left(-13\right.$ to $\left.-16^{\circ} \mathrm{C}\right)$, it is also colder than Barrow (Alaska, $-25.4^{\circ} \mathrm{C}$ ), and Tiksi, at the Lena Delta $\left(-30^{\circ} \mathrm{C}\right)$. Temperatures below $-40^{\circ} \mathrm{C}$ occur regularly. The mean July temperature of $+10.4^{\circ} \mathrm{C}$ is warmer than in Barrow $\left(4.6^{\circ} \mathrm{C}\right)$ and Scoresbysund $\left(6.0^{\circ} \mathrm{C}\right)$, comparable to Tiksi and somewhat cooler than Kiruna and Vorkuta $\left(12-14^{\circ} \mathrm{C}\right)$. Maximum temperatures at the site may reach over $+25^{\circ} \mathrm{C}$. The mean annual temperature is $-10.5^{\circ} \mathrm{C}$. Monthly mean temperatures are quite variable in the winter, and more constant in the summer. Annual mean precipitation amounts to $212 \mathrm{~mm}$, of which about half falls as snow. Snow depths at the site are $60-80 \mathrm{~cm}$ and quite constant throughout the years, this is somewhat more than measured at the long-term weather station near the village. With wind speeds around $4 \mathrm{~m} \mathrm{~s}^{-1}$ the site is amongst the calmer sites, Barrow and Vorkuta in particular experience stronger winds $\left(\sim 5 \mathrm{~m} \mathrm{~s}^{-1}\right)$. Wind directions are distributed fairly even, with a slight preference for northeasterly and southwesterly directions. The average (1998-2006) number of sunshine hours in June, July, August is 275,248 and $136 \mathrm{~h}$ of sun. In 2004, the number of sunhours in June, July and August was in total $384 \mathrm{~h}$ less $(128 \mathrm{~h}$ per month) and in 2005 it was in total $186 \mathrm{~h}$ more (62 h per month). The years 2003 and 2006 had sunshine hours close to the long-term mean.

During the operation years of the site, water level in the nearby river varied considerably, and consequently also on the measurement sites. With respect to 2003, in 2004, the river stage was relatively high after high snowmelt runoff. In 2005 , the river stage was approximately $1.5-2 \mathrm{~m}$ lower, as a result of a dry winter and spring; moreover, the air temperatures were as high as $30^{\circ} \mathrm{C}$ during most of the field campaign. The river stage in 2006 was intermediate.

\subsubsection{Geology and soils}

Three major topographic levels occur around the measurement site (Fig. 2). The highest level is underlain by "Ice complex deposits" or "Yedoma", ice-rich silt deposits of Late Pleistocene, deposited as loess or fluvial silts (Schirrmeister et al., 2002; Gavrilov et al., 2003; Zimov et al., 2006). Near the site, the ice complex deposits occur in terracelike 20-30 m high hills, probably representing a Pleistocene river terrace surface which has been eroded by thermokarst processes. Presence of cross-bedding in a riverbank exposure near the site indicates a fluvial origin of the sediments. The measurement site itself is located in a depression between two N-S trending ice complex remnants, constituting the second topographic level. This depression originated as a thermokarst lake of Holocene age, drained by fluvial erosion. The lowest topographic level is the present river plain, situated 2-3 $\mathrm{m}$ below the lake bottom. The river plain has a conspicuous fluvial relief with levees, back swamps and lakes. Active thermokarst features (slumps and thermoerosional niches) are common along the river bank, and thermo-erosional expansion of creeks and sloughs is also common on the river plain.

The area is underlain by continuous permafrost. The active layer ranges from $25 \mathrm{~cm}$ in dry, peat-covered locations to $40 \mathrm{~cm}$ in wet locations. On the floodplain the active layer may be locally thicker. Both on the floodplain and the lake bottom a network of ice wedge polygons occurs, in general of the low-centered type. The ice wedge polygons on the lake bottom have a more mature appearance, with well developed ridges and wet, low centers. This suggests that the age of this surface is older than that of the river plain. Next to the polygons, also low, flat palsa-like features occur on the lake bottom, representing generally drier areas. The lake bottom is drained by a diffuse network of depressions, covered with a Carex-Eriophorum vegetation and underlain by a generally thicker active layer.

The soils generally have a $10-15 \mathrm{~cm}$ organic top layer overlying silt. In case of wet sites, the organic layer consists of loose peaty material, composed either of sedge roots 


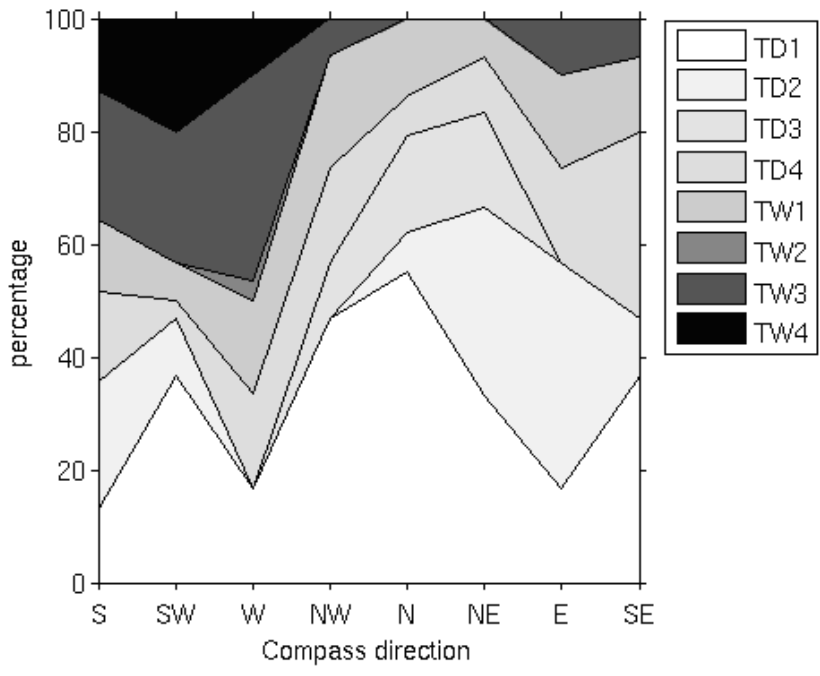

Fig. 3. Areal proportion of vegetation/terrain classes along $150 \mathrm{~m}$ transects in different directions from the tower, TD classes: dry sites with a grass-moss-Betula nana vegetation (TD1,TD3) or Eriophorum hummocks (TD2). TD4 is a dried Sphagnum vegetation with very thin active layer. TW classes: wet sites with a Carex-Eriophorum vegetation (TW1, "sedge meadows"), open water (TW2) or Sphagnum-dominated vegetation (TW3,4). See Table 2 for further description of terrain classes.

or Sphagnum peat, depending on the vegetation. Drier sites tend to have a thinner, more compact organic layer.

The Berelekh river meanders from west to east. In a band of about $30 \mathrm{~km}$ wide, centered at the river, many small lakes occur $(17 \%)$, with diameters of a few hundred meters. In a wider area (about $75 \times 75 \mathrm{~km}$ ) fewer, larger lakes occur (22\%), with typical diameters of $10 \mathrm{~km}$.

Based on a detailed digital map, the fraction of water in the narrow band was estimated at $17 \%$ and at $22 \%$ in the wider area. The relatively large fraction of water needs to be taken into account when interpreting the flux measurements made on land.

\subsubsection{Vegetation composition}

On the Circumpolar Arctic Vegetation Map (CAVM Team, 2003) the area and its surroundings classify as G4 (Tussocksedge, dwarf-shrub, moss tundra) or S2 (Low-shrub tundra). However, within the site and its wide surroundings large tracts of W2 (Sedge, moss, dwarf-shrub wetland) occur and may even dominate. In the area in the immediate surroundings of the tower, the vegetation is a mosaic of: 1) drier sites (palsa, ridges along ice wedges) dominated by Betula nana, Salix sp., mosses and grasses; 2) isolated depressions (polygon centers, thawing ice wedges) dominated by submerged Sphagnum, Potentilla palustris and some Carex, 3) mires with Sphagnum hummocks and some Salix and 4) depressions with a dense Carex-Eriophorum vegetation.
For the methane flux measurements, a classification has been developed, linking vegetation and geomorphology (Van Huissteden et al., 2005; Table 2, Fig. 2). At the highest level, this classification distinguishes between floodplain and river terrace/tundra. Next, dry and wet sites have been distinguished based on water table position, where "wet" is defined as largely water saturated soils, with a water table not lower than $5 \mathrm{~cm}$ below the surface. The lowest level of the classification is based on smaller morphological features and their vegetation. Van Huissteden et al. (2005) give a detailed description of all classes. The areal fraction of the terrain units has been determined by point counting at regular distances along transects, near the eddy correlation flux tower and on the floodplain area near the field station. In general, in the area to the south and west of the tower, the wet TW classes (see Table 2 for code conventions) dominate while to the north and east of the tower the dry TD classes dominate (Fig. 3). On the floodplain, FW2 dominates.

\subsection{Instrumentation}

\subsubsection{Eddy covariance and micrometeorology}

At the site two masts are installed, the first mast contains the eddy covariance instrumentation, consisting of an ultrasonic anemometer (Gill Instruments, Lymington, UK, type R3-50) and an open path infra-red gas analyzer (Licor, Lincoln, NE, USA, type Li-7500) at a height of $4.7 \mathrm{~m}$. Eddy covariance data were collected on a handheld computer (van der Molen et al., 2006) at a rates between 5 and $10 \mathrm{~Hz}$, depending on the time between field visits and storage capacity. It was experimentally verified that reducing the data collection frequency to $5 \mathrm{~Hz}$ did not significantly change the resulting fluxes at the site. Eddy fluxes were computed on a half-hourly basis following the Euroflux methodology (Aubinet et al., 2000) with the addition of the angle of attack dependent calibration (van der Molen et al., 2004; Nakai et al., 2006). Storage flux was corrected for using the discrete approach, which did not significantly change the fluxes however. The second mast contains a shortwave radiometer (Kipp \& Zn, Delft, the Netherlands, type albedometer, CM7b), up- and down facing longwave radiometers (The Eppley Laboratory, Newport, RI, USA, type PIR) and a net radiometer (Campbell Scientific, Logan, UT, USA, type Q7). 20 soil thermometers (made at the Vrije Universiteit Amsterdam) were dug into 2 profiles, each reaching $60 \mathrm{~cm}$ into the ground. The one profile was in a polygon depression, where the soil is more moist, the other profile was on the rim of a polygon with a relatively low water table. Soil moisture was not measured. Small scale variations in topography in relation to polygon mires causes a rather heterogeneous soil moisture field, however, during the entire growing season, the soil moisture conditions are wet. The instruments were usually installed in April each year and taken down for the winter in October. However, because the system was operated on solar power and batteries, 
Table 2. Site classification based on geomorphology, water table position and vegetation. Areal fraction with respect to a $150 \mathrm{~m}$ radius circle around eddy correlation tower for the terrace (T) sites, and on cross transects for the floodplain (F), based on $5 \mathrm{~m}$ distance point counts.

\begin{tabular}{|c|c|c|c|c|c|c|c|}
\hline & Code & Geomorphology & Soil & Areal fraction & $\begin{array}{l}\text { water table } \\
\mathrm{cm}\end{array}$ & $\begin{array}{l}\text { active layer } \\
\mathrm{cm}\end{array}$ & Vegetation, periglacial surface features \\
\hline \multicolumn{8}{|c|}{ Floodplain } \\
\hline Dry & FD1 & Levee & mineral & 0.15 & 20 & $52-54$ & $\begin{array}{l}\text { Tall Salix shrub with moss and lichen } \\
\text { understorey }\end{array}$ \\
\hline Dry & FD2 & $\begin{array}{l}\text { Levee-backswamp } \\
\text { transition }\end{array}$ & mineral & 0.22 & $5-20$ & $25-50$ & $\begin{array}{l}\text { Sedges and grasses, sometimes also } \\
\text { willow and mosses; actively growing } \\
\text { ice wedge polygons }\end{array}$ \\
\hline Wet & FW1 & Low backswamp & organic-mineral & 0.24 & 0 & $40-43$ & $\begin{array}{l}\text { Reddish, short grass vegetation (Arc- } \\
\text { tophila fulva) with some moss and } \\
\text { Caltha palustris }\end{array}$ \\
\hline Wet & FW2 & Backswamp & organic-mineral & 0.39 & 0 & $30-55$ & Tall sedges, rushes, Eriophorum \\
\hline \multicolumn{8}{|l|}{ Terrace } \\
\hline Dry & TD1 & Palsa, polygon ridge & organic on mineral & 0.32 & - & $15-25$ & $\begin{array}{l}\text { Betula nana, grasses, mosses and } \\
\text { lichens. Cracks, small polygons, mud } \\
\text { boils. }\end{array}$ \\
\hline Dry & TD2 & Tussock tundra & organic on mineral & 0.15 & - & $15-25$ & $\begin{array}{l}\text { Eriphorum tussocks, mosses, lichens, } \\
\text { species-rich vegetation }\end{array}$ \\
\hline Dry & TD3 & Dry grass flat & organic on mineral & 0.05 & - & $12-20$ & Short grasses \\
\hline Dry & TD4 & Dry Shagnum flat & organic & 0.15 & - & 20 & $\begin{array}{l}\text { Sphagnum peat overlying permafrost } \\
\text { ice at shallow depth. Sphagnum has a } \\
\text { dry appearance. }\end{array}$ \\
\hline Wet & TW1 & $\begin{array}{l}\text { Depression, } \\
\text { diffuse drainage }\end{array}$ & organic on mineral & 0.13 & $0-5$ & $26-48$ & Tall sedges, Eriophorum \\
\hline Wet & TW2 & $\begin{array}{l}\text { Thawing ice wedge } \\
\text { depression }\end{array}$ & organic, ice & $<0.01$ & 0 & $28-50$ & $\begin{array}{l}\text { Standing water, some Sphagnum and } \\
\text { Carex }\end{array}$ \\
\hline Wet & TW3 & $\begin{array}{l}\text { Low polygon centre, } \\
\text { other depressions }\end{array}$ & organic & 0.13 & $15-20$ & $22-48$ & $\begin{array}{l}\text { Sphagnum, lush green appearrance, of- } \\
\text { ten overgrowing TW1. }\end{array}$ \\
\hline Wet & TW4 & $\begin{array}{l}\text { Low polygon centre, } \\
\text { other depressions }\end{array}$ & organic & 0.05 & $0-5$ & $22-38$ & $\begin{array}{l}\text { Potentilla palustris, Sphagnum and } \\
\text { sedges. }\end{array}$ \\
\hline
\end{tabular}

and the area is inaccessible during the period of snow melt and ice breaking (May), power failures caused the system to shut down in the spring of 2004, 2005 and 2006, but each year's record starts at least within a few days after leaf onset. Low solar radiation conditions cause some gaps in the record during the fall. An additional wind generator was installed in 2006 to help prevent power failures.

\subsubsection{Chamber measurements of the ecosystem respiration} rate of $\mathrm{CO}_{2}$

Observations of the ecosystem respiration rate were made using a portable gas analyzer (PP Systems, Hitchin, UK, type EGM-4) equipped with a closed chamber (type SRC-1) and a soil temperature probe (type STP-1). The chamber has dimensions of (height $\times$ diameter $)=(15 \times 10 \mathrm{~cm})$. 25 aluminium rings on which the chamber fits precisely were installed in the field at various locations with representative vegetation cover, so that the respiration rates were measured each time at the same places without disturbing the soil. The increase in volume was corrected for. Observations were carried out from 27 July to 1 August 2004 (Fig. 7a) and from 26 to 29 June 2005 (Fig. 7b), at 3 hourly intervals. In
2004, 189 individual measurements passed quality control and in 2005,249 . At a few measuring locations, the ecosystem respiration rate is possibly under-estimated, because the rings and chambers could not hold larger plants. However, at most of these sites, the plant cover would not be more than a single twig. Some variation of ecosystem respiration rate was observed between the various locations, but the average fluxes per location varied less than a factor 2 . The differences were not consistent and variations due to temperature and weather were of similar magnitude. We assumed that the mean ecosystem respiration rate over each of the 25 locations as representative for the ecosystem respiration in the footprint of the flux tower.

\subsubsection{Photosynthesis measurements}

On 14 July 2003, measurements of photosynthesis rates were made using a portable LCA-4 (ADC Bioscientific, Herts, UK) Infrared Gas Analyser with leaf cuvettes. On 30 July 2004, a LI-6400 system (Li-Cor, Lincoln, NE, USA) was used. The photosynthetic activity was measured of leaves of Betula, Salix, Eriophorum plants. Of each species 2-3 leaves were sampled and the measurements were repeated 


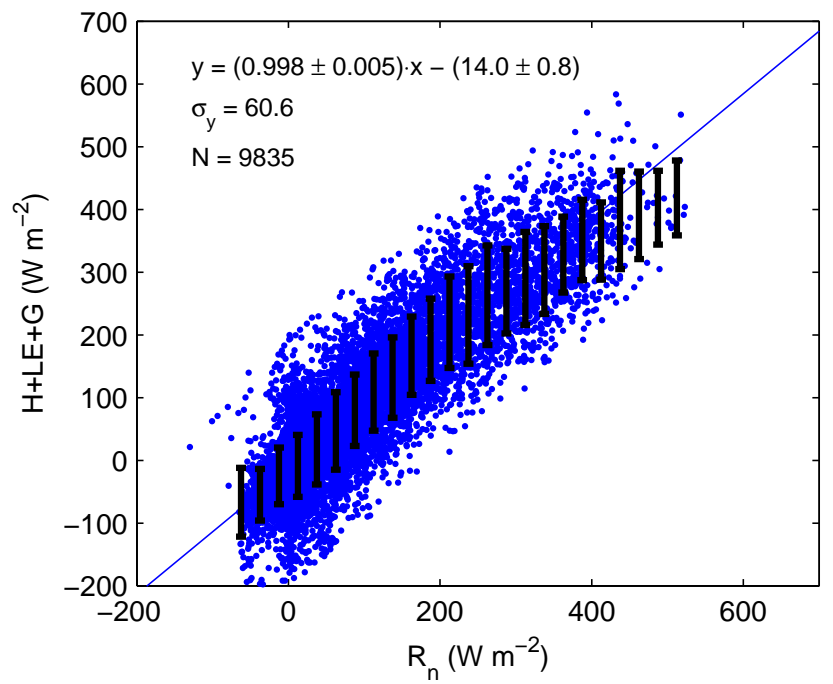

Fig. 4. Energy balance closure based on half hourly fluxes. The $\mathrm{x}$-axis indicates the amount of net radiation $(R n)$ received and the $\mathrm{y}$-axis the amount of energy spent on the sensible $(H)$, latent $(L E)$ and soil heat fluxes $(G)$.

3-5 times. The entire measurement cycle was repeated at three hour intervals during $24 \mathrm{~h}$ periods, using the same leaves. After the last measurement cycle, the leaves were taken to determine the leaf area. No systematic difference in photosynthetic activity was observed between species, and the variation between leaves of the same species was of the same order of magnitude as the variation between species. For this reason the measurements taken in a three hour interval were averaged into a single value.

\subsubsection{Methane flux measurements}

Methane flux measurements were made during a number of consecutive days in the summers of 2004 (27-30 July), 2005 (20-27 July), 2006 (15-18 August). The methane flux measurements were made using static chambers (diameter $30 \mathrm{~cm}$, height 20-30 cm), at 55 sites in 2004, 86 sites in 2005 and 60 sites in 2006, selected from the terrain classes in Table 2 for determination of spatial variation of the fluxes. The round static chambers were attached to a photo-acoustic gas monitor (model 1312, Innova AirTech Instruments, Ballerup, Denmark), capable of measuring $\mathrm{CO}_{2}, \mathrm{H}_{2} \mathrm{O}, \mathrm{N}_{2} \mathrm{O}$ and $\mathrm{CH}_{4}$ concentrations. In 2006 a model 1412 Innova was used, equipped for $\mathrm{H}_{2} \mathrm{O}$ and $\mathrm{CH}_{4}$ measurements. The detection limit for $\mathrm{CH}_{4}$ is $0.1 \mathrm{ppmv}$, resulting in a theoretical minimum detectable flux of $0.13 \mathrm{mg} \mathrm{CH}_{4} \mathrm{~m}^{-2} \mathrm{hr}^{-1}$ given the measurement setup. In total, 201 methane flux measurements have been made during these three field campaigns. For logistic reasons, only a few chambers could be transported to the site. To obtain insight in spatial variation of the methane fluxes we choose for measurement of a large number of sites rather than a few fixed measurement stations, as described by
Table 3. Soil characteristics.

\begin{tabular}{lrrr}
\hline component & fraction & $\begin{array}{r}\text { density } \\
\mathrm{kg} / \mathrm{m} 3\end{array}$ & $\begin{array}{r}\text { specific heat } \\
\mathrm{kJ} / \mathrm{kg} / \mathrm{K}\end{array}$ \\
\hline mineral & $4 \%$ & 2650.00 & 0.90 \\
organic & $36 \%$ & 1300.00 & 1.92 \\
water & $30-60 \%$ & 1000.00 & 4.18 \\
air & remaining & 1.20 & 1.01 \\
\hline
\end{tabular}

Van Huissteden et al. (2005). Installing chambers relatively shortly before measurement could lead to aberrant fluxes due to ebullition. Therefore, a few sites have been measured repeatedly during several days; the measured fluxes proved repeatable. Moreover, each flux measurement was checked for quality by graphing the $\mathrm{CH}_{4}$ concentration against time. Irregular increase of the $\mathrm{CH}_{4}$ concentration was taken as evidence of induced ebullition or leakage of the chamber. These measurements were rejected. Each flux measurement was accompanied by determination of the active layer depth and soil temperatures. At each site characteristics of the vegetation and soil profile, and the water table were recorded, using a hand auger. Each flux measurement was quality controlled following van Huissteden et al. (2005).

\section{Validation of measurements and models}

\subsection{Energy balance closure}

Figure 4 shows the energy balance closure as a method to test the quality of the eddy flux data. The linear least square regression through all data points shows a good energy balance closure of $99.8 \%$ with an offset of $14 \mathrm{~W} \mathrm{~m}^{-2}$ and a standard deviation of $60 \mathrm{~W} \mathrm{~m}^{-2}$. However, the binned data suggest an underestimation of the larger fluxes. The soil heat flux $G$ was estimated here as a function of the change of temperature in the profile and typical soil characteristics as shown in Table 3.

\section{2 $\mathrm{CO}_{2}$ fluxes during calm conditions}

Underestimation of ecosystem $\mathrm{CO}_{2}$ fluxes under calm conditions is amongst the most prominent error sources of the eddy covariance method. Figure 5 shows some indications that this so-called $u_{*}$-problem may occur at the field site for $u_{*}<0.2 \mathrm{~m} \mathrm{~s}^{-1}$, although the underestimation is small compared to what is sometimes observed at other sites (cf. Dolman et al., 2004). Because calm, "night-time" conditions may also occur during the polar day at this high latitude site, we estimate NEE for $u_{*}<0.2 \mathrm{~m} \mathrm{~s}^{-1}$ as follows:

$$
\mathrm{NEE}=R_{\mathrm{eco}, \bmod }-\mathrm{GPP}_{\bmod }\left(u_{*}<0.2 \mathrm{~m} \mathrm{~s}^{-1}\right)
$$


where $R_{\text {eco,mod }}$ and $\mathrm{GPP}_{\text {mod }}$ are model estimates of the ecosystem respiration and photosynthesis rates (see Sects. 3.3 and 3.5).

\subsection{Parameterising the ecosystem respiration rate}

Continuous time series of the ecosystem respiration rate was estimated as the $\mathrm{CO}_{2}$ flux measured with eddy covariance under conditions of low global radiation $\left(<20 \mathrm{~W} \mathrm{~m}^{-2}\right)$ and strong turbulence $\left(u_{*}>0.2 \mathrm{~m} \mathrm{~s}^{-1}\right)$. Figure $6 \mathrm{a}$ shows that the ecosystem respiration rate increases with temperature, but that soil temperature does not explain all the variation. The timing in the growing season appears to explain a large part of the remaining variation, as indicated by the colours of the data points. A linear optimization of the model

$R_{\text {eco } \text { mod }}=R_{0} Q_{10}^{(T / 10)}(180<\operatorname{doy}<240)$

where the base respiration $R_{0}\left(\mu \mathrm{mol} \mathrm{m}{ }^{-2} \mathrm{~s}^{-1}\right)$ is written as a 3rd degree polynomial function of the day-of-year, is shown in Fig. 6b. The optimized parameters are [-8.37E-06, 5.15E$03,-1.04 \mathrm{E}+00,6.94 \mathrm{E}+01]$ with an associated $Q_{10}$ of 1.80 . The rationale for using day-of-year as a proxy for $R_{0}$ is that active layer depth, biomass and substrate co-vary during the growing season and it is as yet impossible to distinguish between those. For dates outside the range 180 to 240, Eq. (2) is fixed to 180 or 240 . The resulting $R_{\mathrm{eco} \text {, mod }}$ has a slope of about 1.0 versus $R_{\text {eco,obs }}$ but with considerable scatter $\left(r^{2}=0.44\right)$. The unexplained part of the variation may be due to heterogeneity of vegetation composition or ground water table. The respiration rate does not vary with wind direction. The respiration rate derived here from the eddy covariance data is compared with the chamber measurements in Sect. 4.2.

\subsection{Validation of partitioning of NEE into $R_{\text {eco }}$ and GPP}

The partitioning of NEE as measured by the eddy covariance method into $R_{\text {eco }}$ and GPP was validated against chamber and leaf level photosynthesis measurements. Figure 7 shows a comparison of the diurnal cycles of respiration rates resulting from Eq. (2) with chamber measurements of the respiration rate for a few consecutive days in 2004 and 2005. Figure 7 shows agreement in the order of magnitude, but there is also considerable variation. Particularly on days 209 and 210 in 2004 (Fig. 7a), the chamber fluxes are larger than the eddy fluxes, but at these days relatively few reliable chamber measurements were made, due to malfunctioning of the battery. From day 211 to 214, when measurements were made at a higher temporal resolution, the agreement is closer. The x's indicate the variability of eddy covariance flux measurements at the corresponding times, for turbulent $\left(u_{*}>0.2 \mathrm{~m} \mathrm{~s}^{-1}\right)$ and dark $\left(R_{g}<20 \mathrm{~W} \mathrm{~m}^{-2}\right)$ conditions.

The photosynthesis rate GPP was estimated as $R_{\mathrm{eco}}-$ NEE. Diurnal cycles of photosynthesis rates were also measured independently (see Sect. 2). Figure 8 shows a good level of

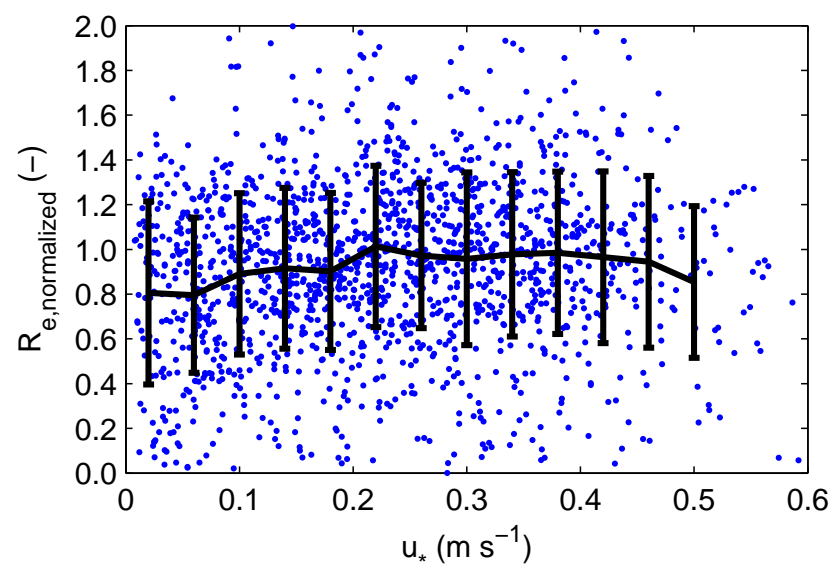

Fig. 5. The ecosystem respiration rate, determined from nighttime $\left(R_{g}<20 \mathrm{~W} \mathrm{~m}^{-2}\right)$ eddy covariance measurements, normalized for temperature and time influences, as a function of $u_{*}$, showing a slight underestimation for $u_{*}<0.2 \mathrm{~m} \mathrm{~s}^{-1}$.

agreement between GPP from the partitioning of eddy fluxes on the one hand and leaf level measurements on the other hand on 14 July 2003 and 30 July 2004. Figure 8 also shows model simulations of GPP, using the ORCHIDEE model that is described in Sect. 3.5. The close agreement in absolute values and in the shape of the diurnal cycles of $R_{\text {eco }}$ and GPP gives confidence in the performance of the method of partitioning NEE into GPP and $R_{\text {eco. }}$.

\subsection{Modelling of photosynthesis and methane fluxes}

The ORCHIDEE photosynthesis model (Krinner et al., 2005; Morales et al., 2005) was used in combination with the PEATLAND-VU methane flux model (van Huissteden and van den Bos, 2003; van Huissteden, 2004). ORCHIDEE simulates GPP as a function of solar radiation, surface temperature, air humidity, air pressure, $\mathrm{CO}_{2}$ concentration and surface conductance (Farquhar, 1980; Ball et al., 1987; Collatz et al., 1992). ORCHIDEE may also be used as a dynamical vegetation model, but in this application only the photosynthesis module was used, without accounting for phenology. The C3 grassland plant functional type was used to simulate the tundra photosynthesis rate, after adapting the $V_{c, \max }$ $\left(V_{j, \max }\right)$ from 60 (120) to 35 (70). The Leaf Area Index was maintained at 1.0. The performance of the ORCHIDEE model for tundra is shown in Fig. 9, using mid summer data, when the vegetation was fully developed. Further validation is provided in Fig. 8, where diurnal cycles of simulated GPP are compared with leaf cuvette measurements and with partitioned eddy covariance measurements. GPP is simulated from 2003 to 2006, for each half hour that the required input variables are available, and is used for gap filling, when meteorological variables were available and eddy fluxes were not available, or when eddy fluxes were rejected due to low turbulence conditions (Eq. 1). 

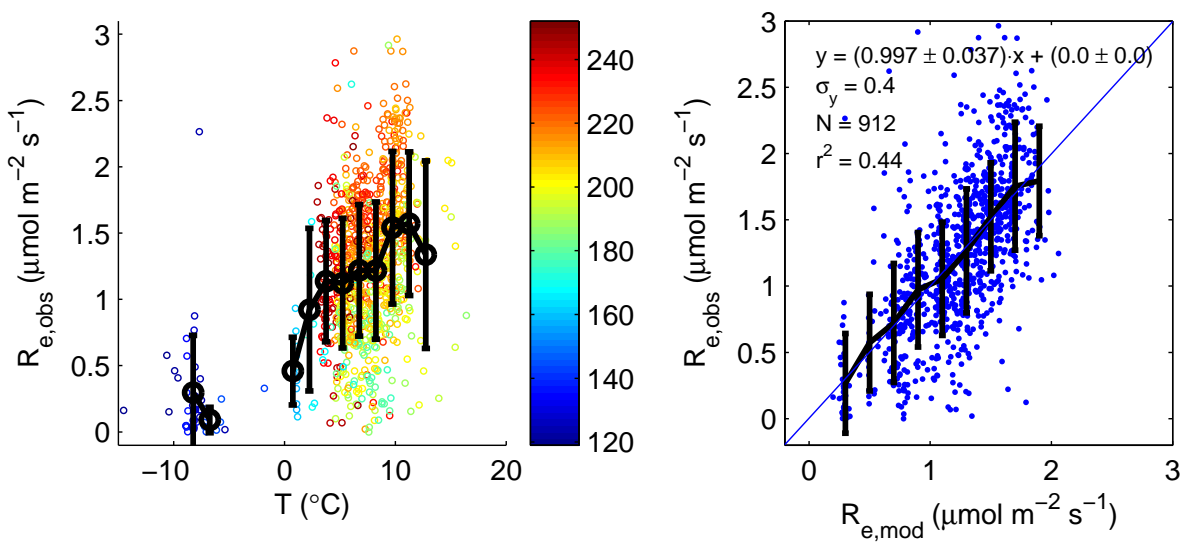

Fig. 6. (a) the variation of observed ecosystem respiration rate as a function of soil temperature and time. (b) performance of the ecosystem respiration model.
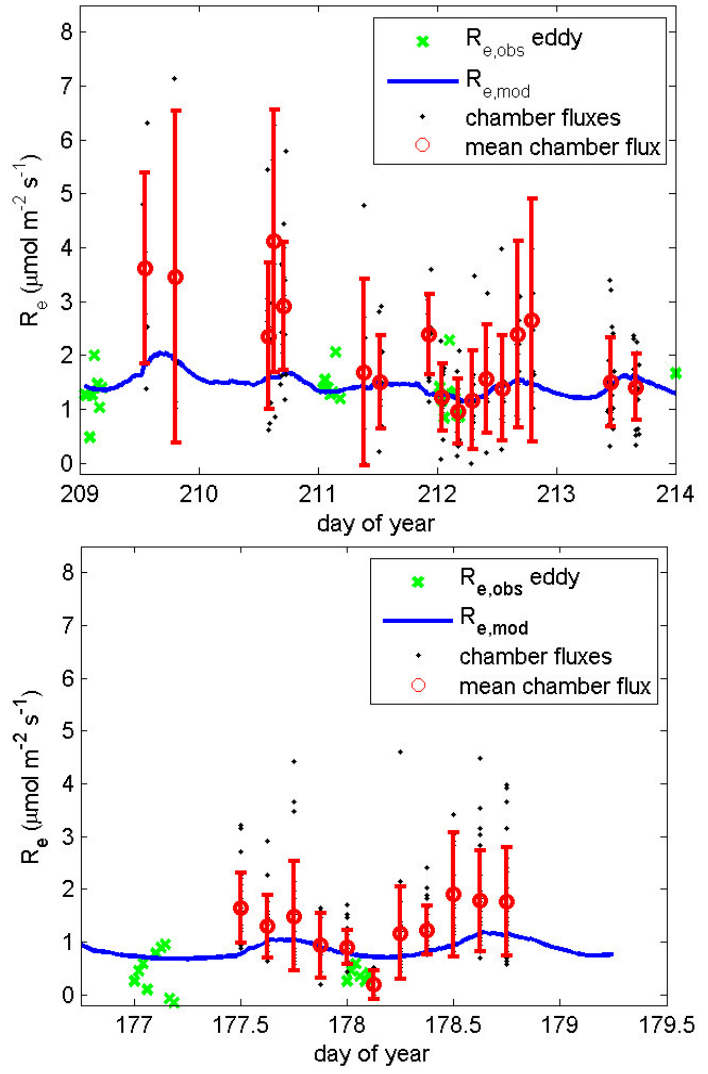

Fig. 7. Comparison of $R_{\mathrm{eco}, \mathrm{obs}}$ : observed respiration rate (nighttime eddy fluxes when $u_{*}>0.2 \mathrm{~m} \mathrm{~s}^{-1}$ ), $R_{\text {eco, } \bmod }$ (Eq. 1), chamber fluxes at individual locations and the mean chamber fluxes. The left figure shows data for 27 July to 1 August 2004 and the right figure for 26 to 29 June 2005 .

PEATLAND-VU simulates $\mathrm{CH}_{4}$ fluxes as the difference of production in the root zone and consumption by oxida-
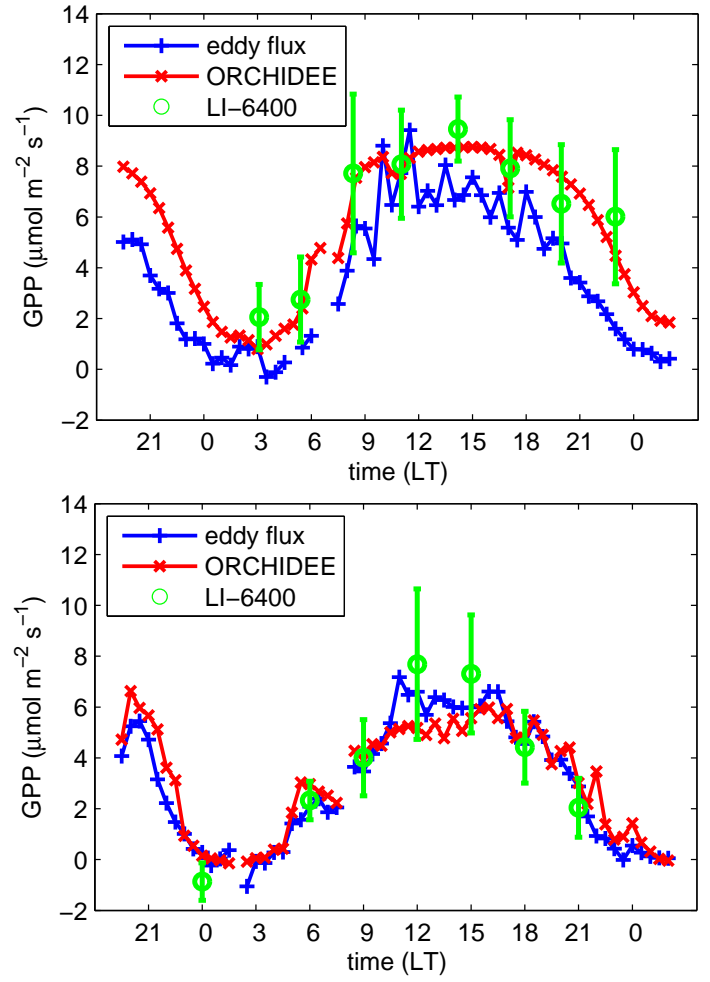

Fig. 8. Diurnal cycles of GPP determined by 1) partition of eddy covariance measurements of NEE, 2) model simulations with ORCHIDEE, using local meteorology and 3) leaf level measurements. The left figure shows the diurnal cycles for 14 July 2003, and the right figure for 30 July 2004.

tion (cf. Walter, 2000). The production is a function of the rate of root exudation of labile organic compounds, which is generally assumed to depend on NPP, as well as a function of the availability of oxygen in the soil. For this purpose, we assume that NPP corresponds to 50\% of GPP (Turner et 

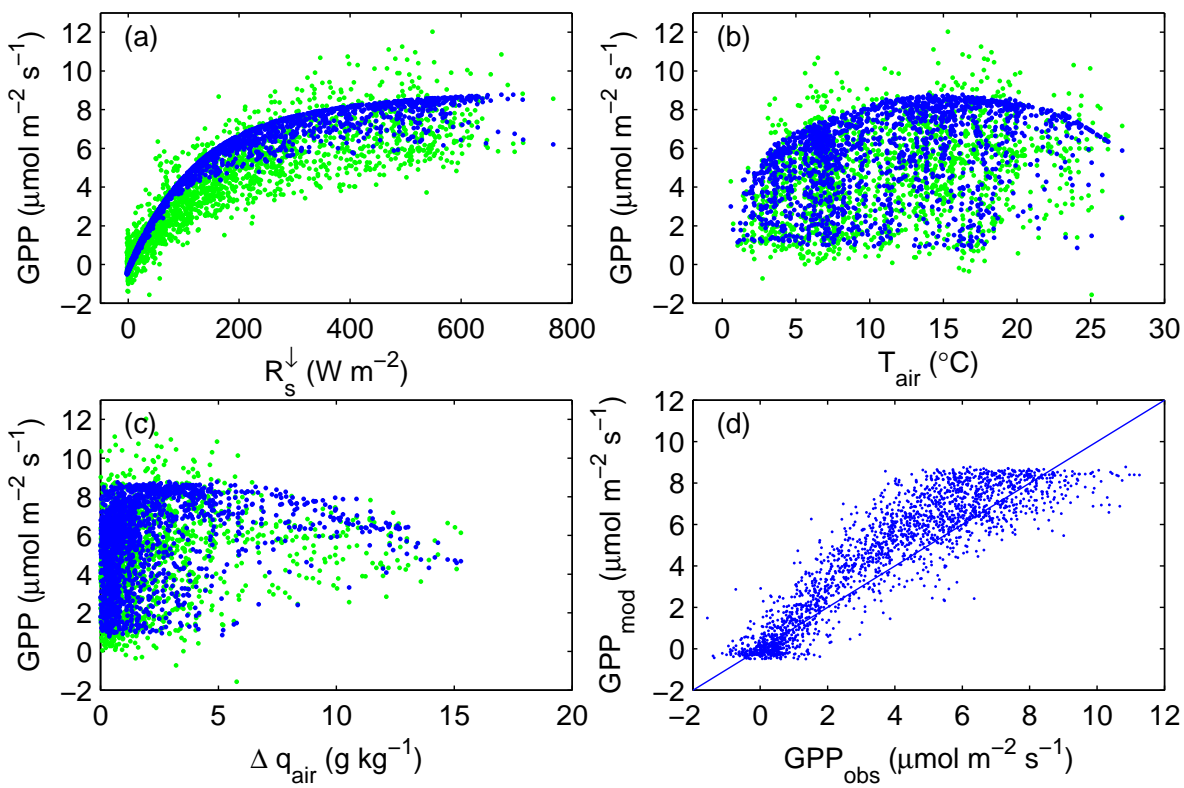

Fig. 9. Performance of the ORCHIDEE model to simulate GPP as a function of (a) global radiation, (b) air temperature (c) vapour pressure deficit. The blue dots represent the modelled GPP and the green ones the GPP obtained by partitioning the observed NEE. (d) shows modelled versus observed GPP. In this comparison data only mid summer data have been used (9 July to 18 August), to exclude dates when the vegetation was not fully grown.

al., 2006), or $125 \%$ of NEE (which are numerically identical in this instance). The NPP input for PEATLAND-VU is derived from the eddy covariance data, augmented with modelled values from ORCHIDEE whenever gaps in the data were present. Oxidation is a function of soil aeration, which varies with ground water table. The ground water table is modelled as a function of the balance between precipitation and evaporation, which are both observed, and snowmelt, using a modified version (Yurova et al., 2007) of the model of Granberg et al. (1999). The modelling of the water table for the site and the methane flux simulations using the modelled water table are described in a separate publication by $\mathrm{Pe}$ trescu et al. (2007). With PEATLAND-VU, methane fluxes were simulated for three different vegetation types representative for the vegetation around the tower site: Carex vegetations (TW1 type), Sphagnum vegetations (TW3-4 type) and dry tundra vegetation (TD types). The NPP generated from the eddy covariance data or ORCHIDEE was used as input for PEATLAND-VU. This was done for 2004 to 2006, so that the model could be verified with the field observations. It was assumed that the ombrotrophic Sphagnum vegetations and dry tundra vegetations had a lower primary production (20\% lower than average NPP) than the TW1 type vegetation (20\% higher than average NPP). On wet sites, oxidation is a function of vegetation species, with Carex species having aerenchyma, which enable efficient transport of methane to the atmosphere, with less oxidation. Sphagnum mosses have a symbiosis with methanotrophic bacteria (Raghoebarsing et al., 2005), resulting in a larger methane oxidation. The vegetation-related parameters (plant transport rate factor and oxidation factor) in the $\mathrm{CH}_{4}$ submodel of PEATLAND-VU have been set accordingly. For the dry sites, water table was set $20 \mathrm{~cm}$ lower than for the wet sites, in line with the field observations made during the methane flux measurements. After initial setting of these parameters, the model output was further optimized on both the methane production rate, a tuning parameter in the model (Walter, 2000), and the plant oxidation rate. The performance PEATLAND-VU model for methane fluxes is shown in Fig. 10, where simulated methane fluxes are plotted versus observed ones, for the three different simulated vegetation types and the three available measurement campaigns. Although the uncertainty ranges are quite wide, the actual values compare rather well. This model was used successfully also for methane fluxes in Stordalen, Abisko, Sweden (Petrescu et al., 2007). The methane model was used to scale up the observed fluxes in time to the complete length of the growing season for the sites around the flux tower. The wet floodplain (FW) have been modelled by Petrescu et al. (2007) but are not considered here because the data from the floodplain do not permit a consistent comparison between $\mathrm{CO}_{2}$ and $\mathrm{CH}_{4}$ fluxes.

\subsection{Comparison of carbon dioxide and methane fluxes}

As the main objective of this paper is to determine the net greenhouse gas budget for this site, it is convenient to express methane fluxes in units of global warming potential. Based on the IPCC 4th Assessment report (Forster et al., 2007), 
Table 4. Comparison of units of methane fluxes. The first row gives conversion factors from methane flux in units $\mathrm{gCH}_{4} \mathrm{~m}^{-2}$ day ${ }^{-1}$ to other the units in the other columns. The second row gives conversion factors from units $\mathrm{gC}_{-} \mathrm{CO}_{2} \mathrm{e} \mathrm{m}^{-2} \mathrm{day}^{-1}$ to units in the other columns. The asterisk-marked column indicates the Global Warming Potential over a 100 year time horizon of $\mathrm{gCH}_{4} \mathrm{~m}^{-2}$ day $^{-1}$, although these units are not used here.

\begin{tabular}{|c|c|c|c|}
\hline $\begin{array}{l}\text { carbon flux units } \\
\mathrm{gC} \mathrm{m}^{-2} \mathrm{day}^{-1}\end{array}$ & $\begin{array}{l}\text { methane mass flux units } \\
\qquad \mathrm{gCH}_{4} \mathrm{~m}^{-2} \text { day }^{-1}\end{array}$ & $\begin{array}{c}\text { GWP units }(*) \\
\mathrm{gCO}_{2} \mathrm{e} \mathrm{m}^{-2} \text { day }^{-1}\end{array}$ & 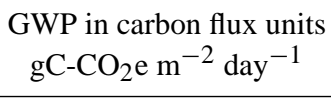 \\
\hline $12 / 16=0.75$ & 1 & 25 & $25 \times(12 / 44)=6.8$ \\
\hline 0.11 & 0.15 & 3.7 & 1 \\
\hline
\end{tabular}

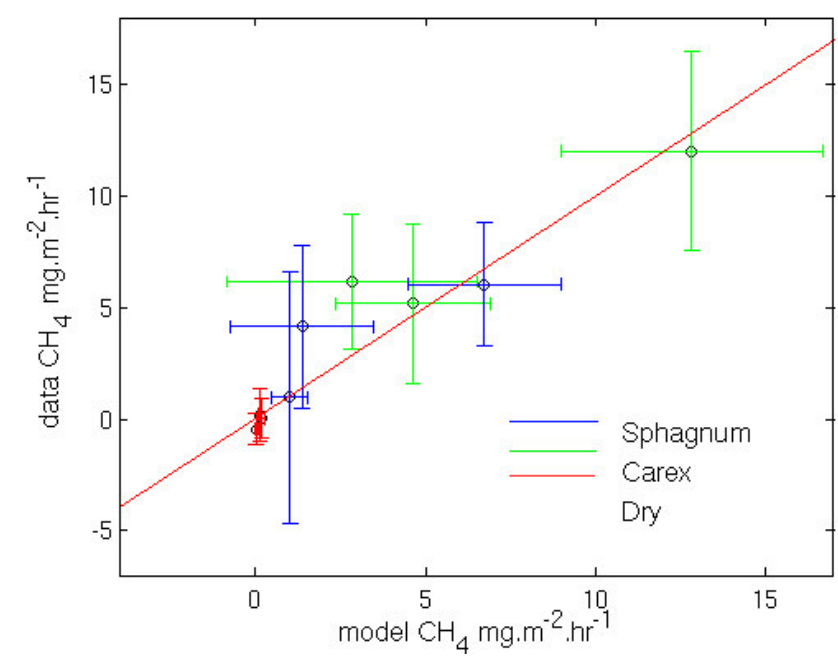

Fig. 10. Validation of the methane fluxes simulated by the PEATLAND-VU model versus observations. Each data point represents the weekly average of methane measurements for the indicated vegetation type in a specific year.

a mass of methane gas has 25 times more global warming potential (GWP) than the same mass of carbon dioxide gas, which has a GWP of 1 by definition. This factor of $25 \mathrm{~g} \mathrm{CO}_{2}$ $\left(\mathrm{g} \mathrm{CH}_{4}\right)^{-1}$ results from integrating the radiative effects of a pulse emission (or removal) over a time horizon of 100 years. The GWP of methane decreases with the integration time, because atmospheric methane oxidises. In terms of GWP, a flux of $1 \mathrm{~g} \mathrm{CH}_{4} \mathrm{~m}^{-2}$ day $^{-1}$ is equivalent to $25 \mathrm{~g} \mathrm{CO}_{2} \mathrm{~m}^{-2}$ day $^{-1}$, or $25 \mathrm{~g} \mathrm{CO}_{2} \mathrm{e} \mathrm{m}^{-2} \mathrm{day}^{-1}$. However, it is common practice to express carbon dioxide fluxes in terms of the mass flux of the carbon atom only. Thus a flux of to $25 \mathrm{~g} \mathrm{CO}_{2} \mathrm{~m}^{-2} \mathrm{day}^{-1}$ is written here as $25 \times(12 / 44)=6.8 \mathrm{~g} \mathrm{C} \mathrm{m}^{-2}$ day $^{-1}$. Table 4 gives an overview and comparison of these units and their numerical value. We use the units of carbon flux in $\mathrm{gC}$ $\mathrm{CO}_{2} \mathrm{e} \mathrm{m}^{-2} \mathrm{day}^{-1}$. For carbon dioxide fluxes this is identical to $\mathrm{g} \mathrm{C} \mathrm{m}^{-2}$ day $^{-1}$ numerically and in terms of global warming potential.

This methodology of assigning methane (and other ghg's) a global warming potential to compare its radiative effects of different greenhouse gasses has been commonly applied since it was adopted in the Kyoto protocol. However, it has a few shortcomings: first, the method strictly only applies for pulse emissions/removals, whereas natural landscapes are better characterized as continuous sources and sinks; second, it only expresses the radiative effects over a fixed time horizon (100 years), whereas in practice the radiative effects evolve dynamically. Over short periods, methane emissions have strong radiative effects, but due to the chemical removal of methane from the atmosphere, the impact decreases over time. Carbon dioxide on the other hand, although being a less effective greenhouse, has a much longer residence time in the atmosphere. Consequently, the radiative effects accumulate and may eventually exceed those of methane. We adopt the methodology of Frolking et al. (2006) to compare the short-term and long-term effects of the carbon dioxide and methane fluxes from this tundra site.

\section{Results}

\subsection{Methane flux measurements}

The methane fluxes show a large spatial and temporal variation. The fluxes measured on the river floodplain (FW classes) are considerably higher than those of the Sphagnumrich sites on the river terrace (TW classes). Only sites in the TW1 class show fluxes that are comparable to those of FW sites (Van Huissteden et al., 2005), although they are still lower (Fig. 11). Dry sites (TD and FD classes) generally show negative fluxes (uptake) and sometimes slightly positive fluxes. Positive fluxes decrease rapidly with lower water table (Van Huissteden et al., 2005).

Compared to van Huissteden et al. (2005), who reported about the 2004 campaign, the 2005 and 2006 field campaigns add to understanding of the temporal variation of the fluxes. Fluxes were highest in 2004, and lowest in 2005, despite the higher the air and soil temperatures. In 2006, the fluxes were intermediate, while the soil surface temperature was lower than in 2005. As such, high fluxes correspond well with high river water levels (Sect. 2.1.1). Statistical analysis shows that methane emission increases significantly with height of the water table and with active layer thickness. Methane emission decreases with surface temperature, and does not 

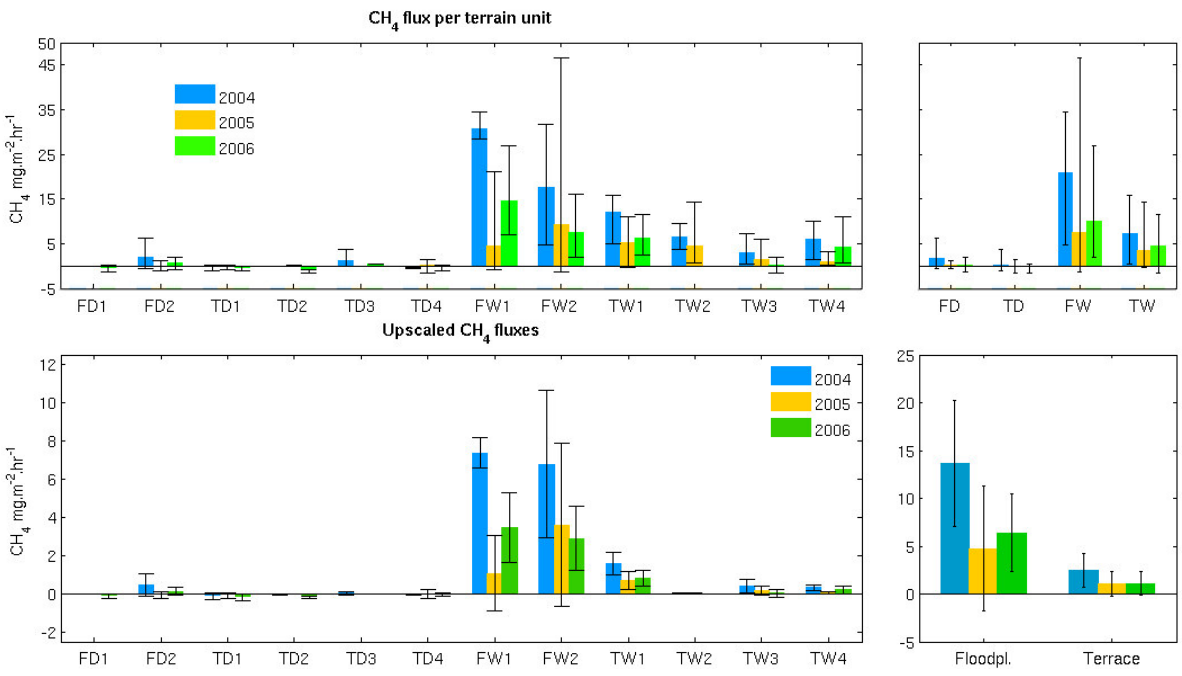

Fig. 11. Top: Average $\mathrm{CH}_{4}$ fluxes per terrain/vegetation unit. The error bars indicate the standard deviation of the average. Top right: averages for all wet and dry groups of terrace and floodplain. Bottom: upscaled fluxes by weighting of the measured fluxes by areal proportion in the terrain.

significantly vary with soil temperature at $10 \mathrm{~cm}$ depth. This surprising results are discussed in Sect. 5.1. The negative fluxes on dry sites do not show any significant correlation with the environmental variables above, albeit that negative fluxes only occur on sites with low water table. Sites where the water table was only a few $\mathrm{cm}$ below the surface may already show negative methane fluxes. At water table depths below $-5 \mathrm{~cm}$, fluxes higher than $5 \mathrm{mg} \mathrm{CH}_{4} \mathrm{~m}^{-2} \mathrm{~h}^{-1}$ do not occur and negative fluxes dominate.

Upscaling of the methane fluxes has been performed by multiplying the fluxes with the areal fraction of the different terrain units. This gives an integrated methane flux for the terrace area around the flux tower and the investigated floodplain area (Table 5, Fig. 11). The integrated fluxes are small on the terrace compared to some of the site fluxes, due to the large relative area of dry sites $(68 \%)$, which are mostly located to the east of the tower. The area to the west of the tower consists of a mosaic of dry and wet sites, associated with polygons. Particularly the polygon ridges contribute to the fraction of drier areas with negative fluxes, a phenomenon that is also known from other Siberian tundra sites (Wagner et al., 2003; Wille et al., 2007). In contrast, only $37 \%$ of the floodplain area consist of dry sites, and mosaic-like pattern are not as pronounced there. Consequently, the contribution of the floodplain sites to the integrated flux is larger considering their small relative area.

\subsection{Seasonal course of carbon dioxide and methane fluxes}

Daily fluxes of NEE, its components GPP and $R_{\text {eco }}$ and methane fluxes are presented in Fig. 12 for the entire period of record. The increase in GPP at the start of the growing sea-
Table 5. Up scaled methane fluxes, based on estimated areal fraction of terrain types on the Terrace/tundra near the eddy correlation tower and on the floodplain. Fluxes are given as $\mathrm{mg} \mathrm{CH}_{4} \mathrm{~m}^{-2} \mathrm{~h}^{-1}$.

\begin{tabular}{cccc}
\hline vegetation class & 2004 & 2005 & 2006 \\
\hline FD1 & $-0.01 \pm 0.01$ & - \pm- & $-0.10 \pm 0.11$ \\
FD2 & $0.46 \pm 0.60$ & $-0.04 \pm 0.18$ & $-0.14 \pm 0.23$ \\
TD1 & $-0.10 \pm 0.16$ & $-0.08 \pm 0.14$ & $-0.15 \pm 0.18$ \\
TD2 & $-0.02 \pm 0.01$ & $0.01 \pm 0.00$ & $-0.18 \pm 0.06$ \\
TD3 & $0.06 \pm 0.09$ & $0.001 \pm 0.001$ & $0.02 \pm 0.003$ \\
TD4 & $-0.06 \pm 0.02$ & $0.01 \pm 0.23$ & $-0.04 \pm 0.10$ \\
FW1 & $7.38 \pm 0.77$ & $1.09 \pm 1.99$ & $3.47 \pm 1.82$ \\
FW2 & $6.79 \pm 3.83$ & $3.61 \pm 4.26$ & $2.91 \pm 1.67$ \\
TW1 & $1.60 \pm 0.60$ & $0.69 \pm 0.47$ & $0.82 \pm 0.40$ \\
TW2 & $0.03 \pm 0.02$ & $0.02 \pm 0.02$ & - \pm- \\
TW2 & $0.41 \pm 0.35$ & $0.19 \pm 0.25$ & $0.03 \pm 0.20$ \\
TW3 & $0.33 \pm 0.15$ & $0.05 \pm 0.08$ & $0.22 \pm 0.20$ \\
Floodplain & $13.66 \pm 6.63$ & $4.76 \pm 6.51$ & $6.41 \pm 4.10$ \\
Terrace/Tundra & $2.46 \pm 1.73$ & $1.08 \pm 1.29$ & $1.11 \pm 1.28$ \\
\hline
\end{tabular}

son of 2003 is remarkably sharp. Uptake by photosynthesis is quite variable from day to day, whereas ecosystem respiration rates vary much slowlier throughout the year. As a consequence, NEE is also quite variable, particularly in a relative sense. The growing season lasts about 60 days, in July and August. The ecosystem respiration increases steadily from the start of the growing season until the second half of $\mathrm{Au}-$ gust, when it starts to decline. Methane fluxes make up a significant part of the greenhouse gas budget and are largest at the onset of the growing season, when wet conditions prevail due to snow melt. Considering that the methane flux in 


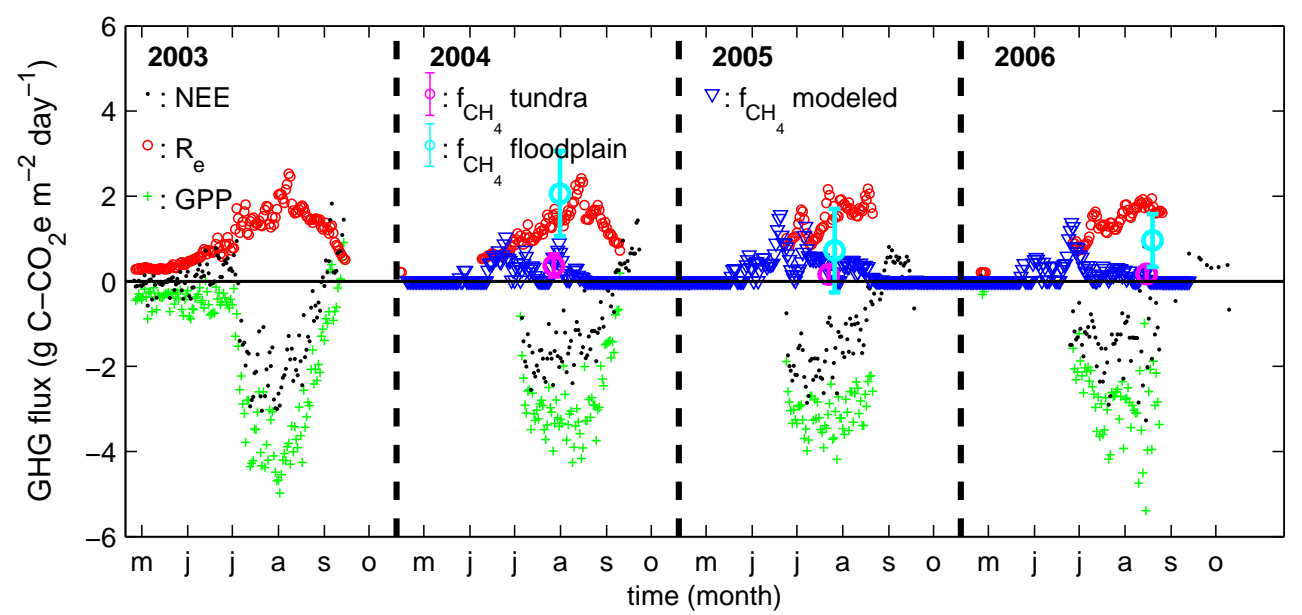

Fig. 12. The seasonal cycles of GPP, $R_{\mathrm{eco}}, N E E$ and methane flux, $f_{\mathrm{CH}_{4}}$. The individual data points represent daily total fluxes, except for the observed methane fluxes (data points with errorbars) which represent weekly averages. The time axis is compressed in the winter months.

carbon flux units (Table 4) is only $12 \%$ of the flux indicated in Fig. 12, the methane fluxes play only a minor role in the carbon budget.

In order to quantify inter-annual variability, daily fluxes were averaged to weekly fluxes and shown in Fig. 13. It appears that interannual variability is small for ecosystem respiration, and larger for GPP and NEE, as well as for methane fluxes. The largest variability in GPP occurs at the start of the growing season, implying that the date of snow melt and the start and length of the growing season are important factors determining the carbon and greenhouse gas balances. The variability at the end of the growing season is smaller, because weather conditions are less important than the limitation due to the shorter day lengths. The lower panels of Fig. 13 again confirm that the greenhouse gas balance is primarily determined by the carbon dioxide component, with a smaller but significant role for methane fluxes. Photosynthesis rates are $3.5 \mathrm{~g} \mathrm{C} \mathrm{m}^{-2} \mathrm{yr}^{-1}$ in the middle of the growing season, and consistently larger in 2003 .

The annually cumulative fluxes are shown in Fig. 14. These fluxes result from averaging the weekly fluxes shown in Fig. 13 over all years and then integrating. It is clear that the net carbon flux NEE is the relatively small difference $\left(-92 \mathrm{~g} \mathrm{C} \mathrm{m}^{-2} \mathrm{yr}^{-1}\right)$ between the large terms of GPP $\left(-232 \mathrm{~g} \mathrm{C} \mathrm{m}^{-2} \mathrm{yr}^{-1}\right)$ and $R_{\text {eco }}\left(+141 \mathrm{~g} \mathrm{C} \mathrm{m}^{-2} \mathrm{yr}^{-1}\right)$, which makes NEE sensitive to relatively small changes in either GPP or $R_{\text {eco. }}$. The methane emissions are $28 \mathrm{~g} \mathrm{C-}$ $\mathrm{CO}_{2} \mathrm{e} \mathrm{m}^{-2} \mathrm{yr}^{-1}$. This is equivalent to a methane emission of $4.1 \mathrm{~g} \mathrm{CH}_{4} \mathrm{~m}^{-2} \mathrm{yr}^{-1}$ and a carbon flux of $3.1 \mathrm{~g} \mathrm{C} \mathrm{m}^{-2} \mathrm{yr}^{-1}$. As a consequence, the greenhouse gas balance is negative, and the site is a net sink of $-64 \mathrm{~g} \mathrm{C}^{-\mathrm{CO}_{2}} \mathrm{e} \mathrm{m}^{-2} \mathrm{yr}^{-1}$. for greenhouse gases.

The uncertainty in annual totals of NEE is typically $40 \mathrm{~g} \mathrm{C} \mathrm{m}^{-2} \mathrm{yr}^{-1}$ (Goulden et al., 1996; Lee et al., 1999; Yang et al., 1999; Lafleur et al., 2001; Baldocchi, 2003). Based on the $\mathrm{CH}_{4}$ flux measurements on the terrace, the coefficient of variation of the measured fluxes is $92 \%$; in Fig. 10 the variation of the modelled values for 5-day periods is similar. Therefore we estimate the uncertainty of the methane

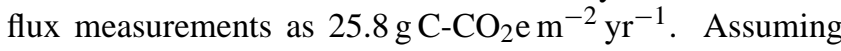
that uncertainty is normally distributed, the confidence level $\alpha$ that the site is a sink for carbon dioxide is $\alpha=0.94$, a source for methane $(\alpha=0.22)$ and a sink for greenhouse gas gases $(\alpha=0.83)$.

Using the methodology of Frolking et al. (2007) to determine the temporal evolution of radiative forcing of sustained carbon dioxide and methane fluxes, we find that on short time horizons ( $<13$ years), the methane emission has stronger radiative impacts than the carbon dioxide sink. However, because the change in atmospheric methane concentration may be considered in equilibrium with the methane source, the radiative forcing due to methane emission has settled at $1.1 \times 10^{-14} \mathrm{~W} \mathrm{~m}^{-2}$ per $\mathrm{m}^{2}$ of tundra source area, which is about $4.4 \times 10^{12} \mathrm{~m}^{2}$ in the Russian Federation and about $8.7 \times 10^{12} \mathrm{~m}^{2}$ worldwide (van der Molen et al., $2007^{1}$ ). Over time horizons longer than 13 years, the radiative effect of the sustained carbon dioxide removal from the atmosphere becomes dominant. Considering the age of tundra is older than that, this site may be considered a sink of greenhouse gasses and acts to cool the climate.

\section{Discussion}

\subsection{Methane fluxes}

A main feature of the $\mathrm{CH}_{4}$ fluxes is the very high spatial variability which is related to vegetation and water table variability. The water table effect is directly related to anaerobic conditions in the soil and has been documented by many authors (Bartlett et al., 1992; Friborg et al., 2000; Heikinnen et al., 


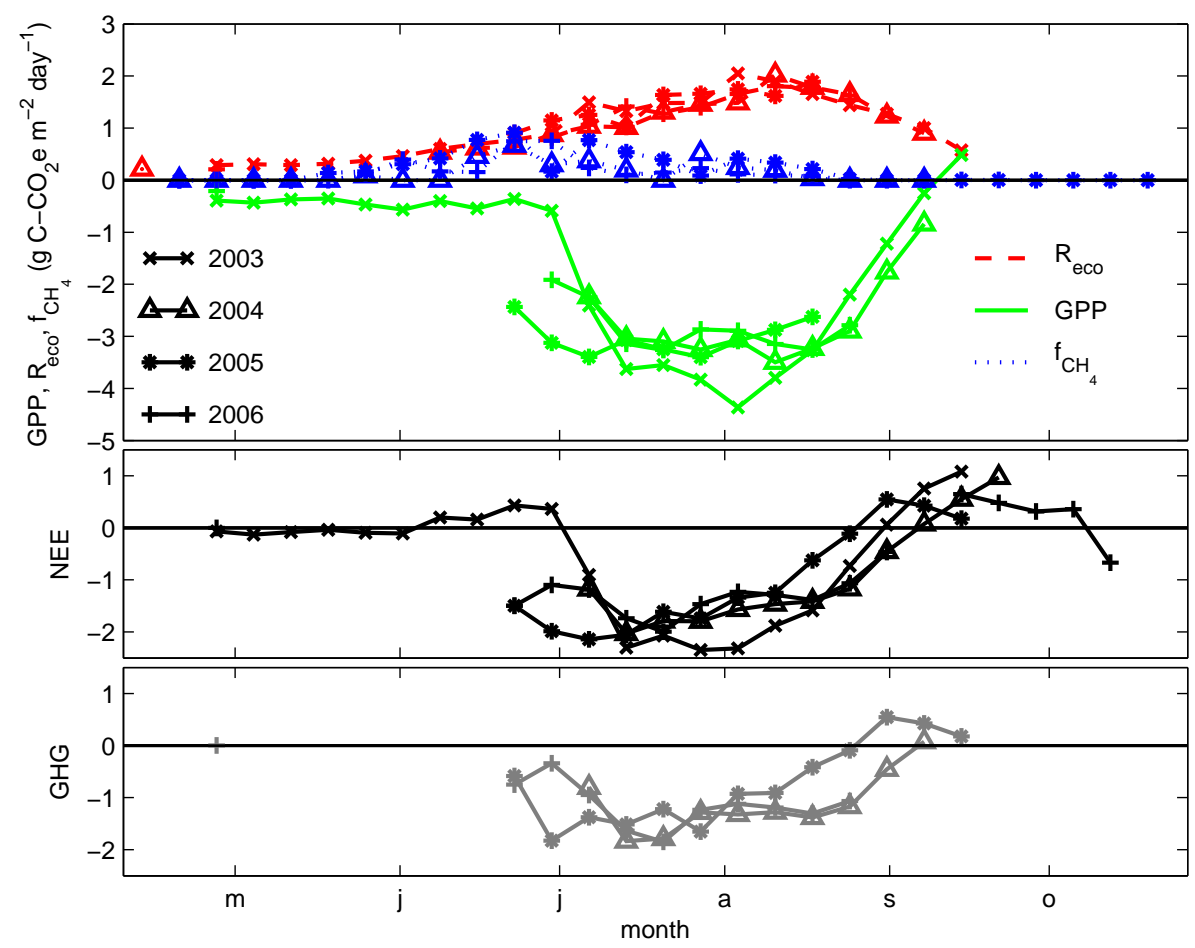

Fig. 13. The interannual variability in the seasonal cycles of $R_{\mathrm{eco}}$, GPP, $f_{\mathrm{CH}_{4}}$ (upper panel) and NEE and the net GHG balance (lower panel). The data points represent weekly mean daily fluxes. The lower panel has the same scale as the upper panel.

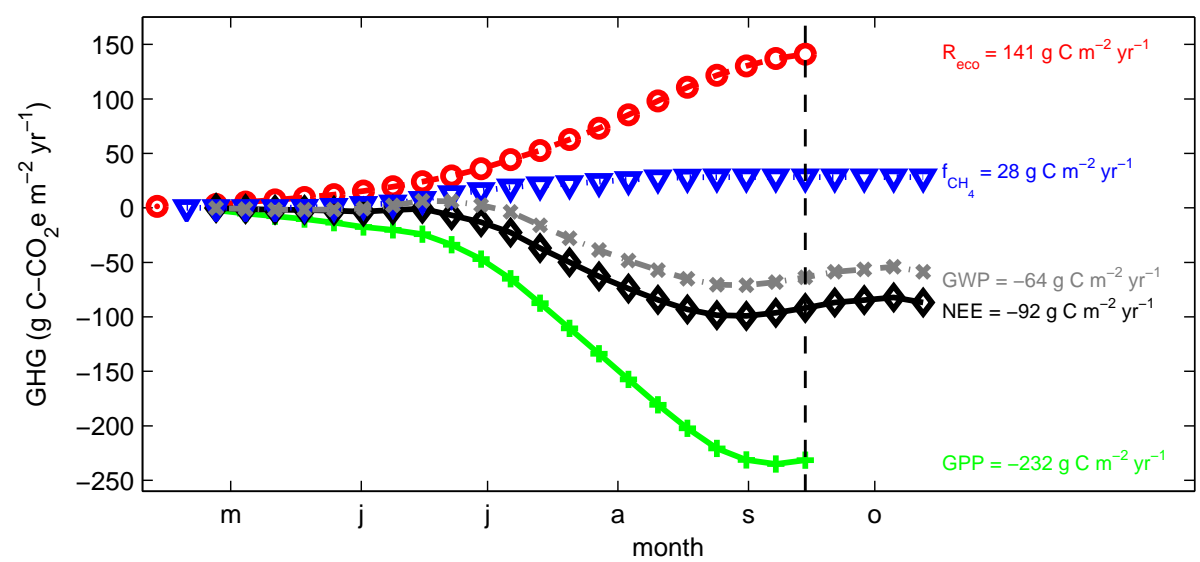

Fig. 14. Annually cumulative GPP, $R_{\mathrm{eco}}$, NEE and methane fluxes and the resulting GHG balance. The numbers at the right indicate the total flux in mid September, indicated by the vertical dashed line, when eddy covariance measurements were no longer available.

2002; Oberlander et al., 2002; Wagner et al., 2003; Kutzbach et al., 2004). Statistical analysis shows that the spatial heterogeneity of the terrain mainly affects water table variation, and soil temperature to a much smaller extent. The correlation patterns with soil temperature and active layer thickness further confirm the dominating effect of the water table. The negative correlation of soil surface temperature and the poor correlation of soil temperature at $10 \mathrm{~cm}$ depth with methane emission rates seems to contradict the often reported posi- tive effect of temperature on methane fluxes of higher soil temperatures, related to microbial reaction rates (cf. Morrissey and Livingston, 1992; Christensen et al., 1995, 2003; Verville et al., 1998; Treat et al., 2007). We hypothesize that this reflects the evaporative cooling effect of the wet soil surface, and the generally thinner active layer on the terrace. Also the adaptation of the microbial population to low temperatures, causing high production rates even at near-zero temperatures, contributes to the low temperature sensitivity 
of the $\mathrm{CH}_{4}$ fluxes (Wagner et al., 2003; Rivkina et al., 2007). Apparently, the sensitivity of $\mathrm{CH}_{4}$ fluxes to temperature pertains rather to large scale variations between sites at different latitudes (Christensen et al., 2003) than within-site and short-term temporal variation in temperature. The positive correlation of methane flux with active layer depth may be a secondary effect. High water tables increase the methane flux but flooding also tends to increase active layer thickness (French, 1996, and references therein). Also, the active layer thickness co-varies with substrate availability throughout the season (see above). The main driver of methane emission is water table, which determines soil temperature and active layer thickness as well, particularly on the river terrace.

Water table also drives the temporal variability of the $\mathrm{CH}_{4}$ fluxes. On a year-to-year time scale there appears to be no clear influence of temperature. This does not exclude that the temperature influence should operate on a seasonal time scale, but as yet our observations lack full seasonal coverage. However, Wagner et al. (2003) also report absence of any correlation of $\mathrm{CH}_{4}$ fluxes with soil temperature from a site in the Lena delta. The relation of $\mathrm{CH}_{4}$ flux to water table depth is approximately exponential, the fluxes decrease very rapidly with lower water table. The river water stage appears particularly important for parts of the floodplain.

The sensitivity of the methane fluxes to water table rather than soil temperature has an important implication for climate change effects on $\mathrm{CH}_{4}$ fluxes from tundra landscapes. An increase of precipitation and river water discharge will have a strong influence on the methane fluxes, perhaps larger than an increase in soil temperature. In particular changes in river regime will have a comparatively large influence, since the $\mathrm{CH}_{4}$ production on the floodplain is comparatively large (Van Huissteden et al., 2005). The difference between soil warming and soil wetness effects need further quantification for a better appraisal of climate change effects on methane fluxes from arctic landscapes.

\subsection{Carbon dioxide fluxes}

The small-scale heterogeneity that is so prominent in the methane fluxes, is much less pronounced for carbon dioxide fluxes. Both the ecosystem respiration rates and photosynthesis rates, measured with chambers and leaf cuvettes, were variable in time and between sites, but the amount of variation is in the order of a factor of two, and not orders of magnitude, as for methane. The variation in GPP and $R_{\text {eco }}$ could not be well explained by vegetation type, water table depth or active layer thickness. Moreover, soil temperature appears to determine the ecosystem respiration rates only to a limited extend (Fig. 6), as was also observed for methane. We hypothesize that small scale variations in hydrology, soil temperature, soil composition, organic matter content, active layer depth and soil moisture/water table depth are interrelated in such a complex way that the current measurements are insufficient to untangle their individual influences.
Photosynthesis appears mainly limited by radiation (Fig. 4) and much less by temperature or vapour pressure deficit. Based on the sunhour anomalies (Sect. 2.1.1), where 2004 had significantly less and 2005 significantly more sunhours than climatologically normal, whereas 2003 and 2006 are close to normal, the photosynthesis rates would be expected to change accordingly. This is however, not the case. Instead, photosynthesis rates are largest in 2003 and relatively small in 2006. The explanation of this apparent inconsistency is that the sunhour anomalies do not correlate well with the relative frequency of global radiation levels below the threshold of $200 \mathrm{~W} \mathrm{~m}^{-2}$, when photosynthesis becomes severely radiation limited (Fig. 9). Instead, the relative frequency of radiation limitation occurs more than average in 2003 and below average in 2006. In 2004 and 2005, this frequency is close to the mean. This implies that photosynthesis rates indeed mainly depend on the occurrence of radiation limitation. During daytime, severe cloudiness is required to reduce global radiation levels below the threshold of $200 \mathrm{~W} \mathrm{~m}^{-2}$. In this perspective, the absence of large mountain ranges in northern zone of Siberian tundra may be a relevant difference with Alaska, considering the relationship between topography and frontogenesis that was shown for Alaska (Lynch et al., 2001). Photosynthesis rates are not often limited by temperature, except for temperatures below $4^{\circ} \mathrm{C}$. Figure $4 \mathrm{~b}$ shows that in the temperature range between 10 and $20^{\circ} \mathrm{C}$, not much gain in maximum photosynthesis capacity may be expected. Similarly, vapour pressure deficit does not often limit photosynthesis and high vapour pressure deficits are actually quite rare.

\subsection{Temporal and spatial upscaling}

Because our measurement setup depends on solar energy, and because of the harsh climate and the inaccessibility of the area, we were unable to measure carbon dioxide and methane fluxes in the winter period. Where previously it was thought that carbon dioxide and methane emissions from frozen soils are negligible, evidence is accumulating that they may actually make up a considerable part of the annual balances. Wintertime carbon dioxide emissions may be 1.3$10.9 \mathrm{~g} \mathrm{C} \mathrm{m}^{-2}$ winter ${ }^{-1}$ in Alaska (Fahnestock et al., (1998),

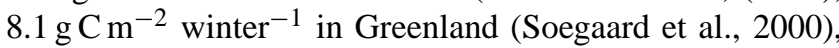
4-6 $\mathrm{g} \mathrm{C} \mathrm{m}^{-2}$ winter $^{-1}$ in Vorkuta, European Russia (Heikinnen et al., 2002). These numbers often amount to about $20 \%$ of the annual sum (Chapin et al., 2000). It should be mentioned though that due to the more continental climate in Chokurdakh, the soil temperatures of $\pm-14^{\circ} \mathrm{C}$ in the springs of 2004,2005 and 2006 and around $\pm-10^{\circ} \mathrm{C}$ in 2007 (probably as a result of the deeper snow) are much colder than observed in Alaska ( -5.6 to $-3.6^{\circ} \mathrm{C}$, Fahnestock et al., 1998). Winter time methane emissions may be between 0.2 and $0.8{\mathrm{~g} \mathrm{C}-\mathrm{CH}_{4} \mathrm{~m}^{-2} \text { winter }}^{-1}$ with a peak emis-

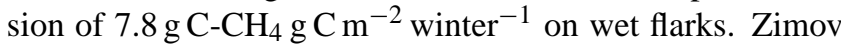

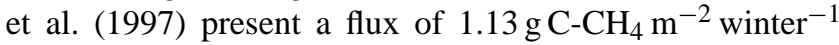


from Siberian lakes. Thus winter fluxes of carbon dioxide may be relatively small compared to the summer time NEE, but winter time methane fluxes may contribute up to an extra $25 \%$ of the summer fluxes. The relative importance of methane emissions may be explained by the anaerobic conditions that may prevail in frozen, snow covered soils (Corradi et al., 2005). Also, microbial metabolism in general and production of $\mathrm{CH}_{4}$ in particular, has been shown to continue at subzero temperatures in arctic soils (Rivkina et al., 2000, 2007; Panikov and Sizova, 2006; Wagner et al., 2007). Assuming a winter carbon dioxide flux of $5 \mathrm{~g} \mathrm{C} \mathrm{m}^{-2} \mathrm{yr}^{-1}$ and a winter methane flux of $1 \mathrm{~g} \mathrm{C} \mathrm{m}^{-2} \mathrm{yr}^{-1}=9 \mathrm{~g} \mathrm{C}-\mathrm{CO}_{2} \mathrm{e}$ $\mathrm{m}^{-2} \mathrm{yr}^{-1}$, would change the NEE to $-87 \mathrm{~g} \mathrm{C} \mathrm{m}^{-2} \mathrm{yr}^{-1}$, the

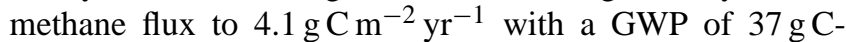
$\mathrm{CO}_{2} \mathrm{e} \mathrm{m}^{-2} \mathrm{yr}^{-1}$, and the GHG balance from -64 to $-50 \mathrm{~g}$ C-CO $\mathrm{C} \mathrm{m}^{-2} \mathrm{yr}^{-1}$.

In Sect. 2.1.2 it was mentioned that near $20 \%$ of the area surrounding the site consists of surface water. As the carbon dioxide exchange between lakes and the atmosphere is probably smaller than between land and the atmosphere, whereas methane emissions from lakes may be larger than from dry land (Bartlett et al., 1992), the greenhouse gas balance of the larger area is probably more neutral than presented in Fig. 14. At present, information about which fraction of the larger area is covered with floodplain is lacking. Therefore we have not taken the contribution of floodplains into account in the upscaling, which would cause an underestimation of the methane emission.

\subsection{Short-term and long-term sensitivity}

On the short-term, the carbon dioxide balance of this tundra ecosystem may be influenced by primarily photosynthesis rates as a function of cloud-radiation interactions and by respiration rates via temperature. Another short-term change may be through changes in the length of the growing season. All other things remaining equal, Fig. 14 suggests that longer growing seasons are in favour of a stronger carbon dioxide sink if thawing starts earlier, but in favour of a reduced sink if the end of the growing season is postponed. This difference is because respiration is limited by temperature at the start, whereas photosynthesis is limited by sunlight at the end of the season. Apart from light limitation, phenology also determines photosynthesis rates. Methane fluxes are most directly affected by changes in the hydrological cycle (Moore et al., 1993; Walter et al., 1996).

On the longer-term, changes in climate may impact the carbon dioxide balance through changes in vegetation composition and permafrost conditions, whereas methane fluxes depend on vegetation composition as well and on hydrology. We should be very careful to explain our observations in the perspective of climate change on the longer-term. Vegetation composition changes have been observed to occur in Alaska (Jia et al., 2003; Lloyd et al., 2003; McGuire et al., 2003; Wilmking et al., 2006) as well as for western Siberia (Esper and Schweingruber, 2004), but similar studies in NE Siberia are lacking.

\subsection{Comparison with other sites}

A comparison of the carbon dioxide and methane fluxes observed in Chokurdakh with those observed at other arctic tundra sites is given in Table 6. The mean daily carbon dioxide flux is within the range observed for different vegetation types in Greenland. On an annual scale, the carbon dioxide sink is quite a bit larger than observed at other sites. Some sites in Alaska and Greenland even act as sources of carbon dioxide. The smaller NEE at other sites may be explained by the smaller GPP at Vorkuta (Heikinnen et al., 2002) and the larger $R_{\text {eco }}$ at Toolik Lake (Oberbauer et al., 1998). The smaller NEE at Greenland (Soegaard et al., 2000) may be explained by the shorter growing season there. Possibly, a general explanation of the large NEE is that the site experiences a more continental climate than other sites, so that ecosystem respiration is limited by the cold soils, with temperatures lagging behind the air temperatures, but with warm summers, which stimulates photosynthesis. Daily methane fluxes are variable between the sites, due to vegetation, and change substantially during the season. Nevertheless, the daily methane fluxes are well in the range found in the literature, be it often on the larger side. Annual fluxes are also quite comparable between sites, with the exception of the fluxes measured in the floodplains of the Kolyma river (Corradi et al., 2005), which are much higher, probably as a result of the high water table and the high nutrient availability.

\section{Conclusions}

At an arctic tundra site in North East Siberia, near the village of Chokurdakh in the lowlands of the Indigirka river, we observed an mean annual carbon dioxide flux of $-92 \mathrm{~g} \mathrm{C} \mathrm{m}^{-2} \mathrm{yr}^{-1}$, which is the net result of $232 \mathrm{~g} \mathrm{C} \mathrm{m}^{-2} \mathrm{yr}^{-1}$ of uptake by photosynthesis and a release of $141 \mathrm{~g} \mathrm{C} \mathrm{m}^{-2} \mathrm{yr}^{-1}$ as ecosystem respiration. The mean an-

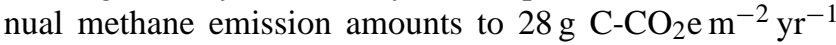
(=4.1 $\left.\mathrm{g} \mathrm{CH}_{4} \mathrm{~m}^{-2} \mathrm{yr}^{-1}\right)$, so that the net greenhouse gas bal-

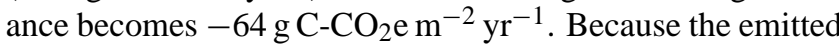
methane is removed from the atmosphere by oxidation, the radiative effect of the sustained carbon dioxide sink dominate over time horizons longer than 13 years, which, considering the old age of the site, means that the site acts to cool the global climate. The greenhouse gas balance would probably be more neutral if winter fluxes and the percentage of lakes and floodplains would be taken into account. The net carbon dioxide flux is large compared to other arctic tundra sites, probably as a result of the more continental climate. On the short-term, photosynthesis appears to depend most on the frequency of radiation limitation due to severe cloudiness, ecosystem respiration rates depend on temperature, but 
Table 6. Comparison of daily and annual carbon dioxide and methane fluxes measured at arctic tundra. In some occasions, hourly fluxes were integrated to daily fluxes by multiplying with $24 \mathrm{~h}$ per day.

\begin{tabular}{|c|c|c|c|c|c|c|c|c|}
\hline region & site & vegetation type & remarks & \multicolumn{2}{|c|}{ NEE } & \multicolumn{2}{|c|}{$\mathrm{CH}_{4}$ flux } & reference \\
\hline & & & & $\begin{array}{c}\mathrm{gC} \\
\mathrm{m}^{-2} \mathrm{~d}^{-1}\end{array}$ & $\mathrm{~m}^{-2} \mathrm{yr}^{-1}$ & $\begin{array}{l}\mathrm{gC}-\mathrm{CO}_{2} \mathrm{e} \\
\mathrm{m}^{-2} \mathrm{~d}^{-1}\end{array}$ & $\begin{array}{l}\mathrm{gC}_{-} \mathrm{CO}_{2} \mathrm{e} \\
\mathrm{m}^{-2} \mathrm{yr}^{-1}\end{array}$ & \\
\hline Alaska & Barrow & wet sedge tundra & & - & -55.5 & - & - & Kwon et al., 2006 \\
\hline Alaska & Barrow & moist tussock tundra & & - & +18.3 & - & - & Kwon et al., 2006 \\
\hline Alaska & Yuken-K. Delta & wet meadow & & - & - & 0.90 & - & Bartlett et al., 1992 \\
\hline Alaska & Yuken-K. Delta & small tundra lakes & & - & - & 0.48 & - & Bartlett et al., 1992 \\
\hline Alaska & Toolik Lake & tussock tundra & & 0.32 & - & $0.01-0.06$ & - & Oberbauer et al., 1998 \\
\hline Alaska & Toolik Lake & wet sedge meadow & control & - & - & 0.50 & 30.7 & King et al., 1998 \\
\hline Alaska & Toolik Lake & wet sedge meadow & moss removal & - & - & 0.53 & 36.1 & King et al., 1998 \\
\hline Alaska & Toolik Lake & wet sedge meadow & sedge removal & - & - & 0.04 & 3.8 & King et al., 1998 \\
\hline Greenland & Zackenberg & Cassiope heath & & -0.60 & - & 0.00 & - & Christensen et al., 2000 \\
\hline Greenland & Zackenberg & overall & & -2.30 & - & 0.29 & - & Christensen et al., 2000 \\
\hline Greenland & Zackenberg & fen area & July & - & - & 0.75 & 23.2 & Friborg et al., 2000 \\
\hline Greenland & Zackenberg & fen area & Aug & - & - & $0.06-0.09$ & - & Friborg et al., 2000 \\
\hline Greenland & Zackenberg & integrated & pre-season & - & 8.4 & - & - & Soegaard et al., 2000 \\
\hline Greenland & Zackenberg & integrated & growing season & - & -18.8 & - & - & Soegaard et al., 2000 \\
\hline Greenland & Zackenberg & integrated & winter & - & 8.1 & - & - & Soegaard et al., 2000 \\
\hline Greenland & Zackenberg & integrated & all year & - & -2.3 & - & - & Soegaard et al., 2000 \\
\hline Greenland & Zackenberg & fen + grass & all year & - & -18.8 & - & - & Soegaard et al., 2000 \\
\hline Greenland & Zackenberg & heath & all year & - & 5.2 & - & - & Soegaard et al., 2000 \\
\hline Greenland & Zackenberg & willow & all year & - & 0.6 & - & - & Soegaard et al., 2000 \\
\hline Sweden & Stordalen & bogs+mires & eddy covariance & - & - & 0.46 & - & Christensen et al., 2004 \\
\hline Sweden & Stordalen & bogs+mires & chambers & - & - & $0.40-0.45$ & - & Christensen et al., 2004 \\
\hline Eur. Russia & Vorkuta & tundra wetland & & - & -29.0 & - & 4.9 & Heikinnen et al., 2002 \\
\hline Siberia & Cherskii & Carex grassland & & - & - & 0.46 & - & Tsuyuzaki et al., 2001 \\
\hline Siberia & Cherskii & Eriophorum grassland & & - & - & -0.01 & - & Tsuyuzaki et al., 2001 \\
\hline Siberia & Cherskii & tussock tundra & & - & -38.0 & - & 100 & Corradi et al., 2005 \\
\hline
\end{tabular}

also on water level, active layer depth and time in the growing season. Methane fluxes are highly variable on small spatial scales. This heterogeneity is primarily related to depth of the water table and on the occurrence of vegetation types with aerenchyma, to transport methane from the soil to the atmosphere. Further variation may be explained by the exudation of labile organic compounds by plant roots, which is related to photosynthesis rates, soil temperature, and active layer depth. The methane fluxes are insensitive to soil temperature but depend strongly on changes in hydrologic conditions. Potential positive feedbacks between climate change and arctic methane fluxes are likely to be governed by precipitation increase next to warming for this continuous permafrost area.

Acknowledgements. The investigations were supported by the Research council for Earth and Life Sciences (ALW) with financial aid from the Netherlands Organization for Scientific Research (NWO, grant no. 854.00.018) and the Darwin Center for Biogeology of ALW/NWO and by the European Commission under the Fifth Framework Programme TCOS-Siberia (EVK2-2001-00143).

Edited by: T. R. Christensen 


\section{References}

Anderson, J. R., Hardy, E. E., Roach J. T., and Witmer R. E.: A land use and land cover classification system for use with remote sensor data, U.S. Geological Survey Professional Paper, 964, 28 pp., 1976.

Aubinet, M., Grelle, A., Ibrom, A., Rannik, ., Moncrieff, J., Foken, T., Kowalski, A. S., Martin, P. H., Berbigier, P., Bernhofer, Ch., Clement, R., Elbers, J., Granier, A., Grünwald, T., Morgenstern, K., Pilegaard, K., Rebmann, C., Snijders, W., Valentini, R., and Vesala, T.: Estimates of the annual net carbon and water exchange of forests: The EuroFlux methodology, Adv. Ecol. Res., 30, 113-176, 2000.

Baldocchi, D. D: Assessing the eddy covariance technique for evaluating carbon dioxide exchange rates of ecosystems: past, present and future, Glob. Change Biol., 9, 479-492, 2003.

Ball, J., Woodrow, T., and Berry, J.: A model predicting stomatal conductance and its contribution to the control of photosynthesis under different environmental conditions, Prog. Photosyn., 4, 221-224, 1987.

Bartlett, K. B., Crill, P. M., Sass, R. L., Harriss, R. C., and Dise, N. B.: Methane emissions from tundra environments in the YukonKuskokwin Delta, Alaska, J. Geophys. Res., 97(D15), 16645$16660,1992$.

Cao, M., Gregson, K., and Marshall, S.: Global methane emissions and its sensitivity to climate change, Atmos. Env., 32, 32933299, 1998.

Chapin III, F. S., McGuire, A. D., Randerson, J., Pielke Sr., R. A., Baldocchi, D., Hobbie, S. E., Roulet, N., Eugster, W., Kasischke, E., Rastetter, E. B., Zimov, S. A., and Running, S. W.: Arctic and boreal ecosystems of western North America as components of the climate system, Glob. Change Biol., 6, 211-223, 2000.

Chapin III, F. S., Sturm, M., Serreze, M. C., McFadden, J. P., Key, J. R., Lloyd, A. H., McGuire, A. D., Rupp, T. S., Lynch, A.H., Schimel, J. P., Beringer, J., Chapman, W. L., Epstein, H. E., Euskirchen, E. S., Hinzman, L.D., Jia, G., Ping, C.-L., Tape, K.D., Thompson, C. D. C., Walker, D. A., Welker, J. M.: Role of Land-Surface Changes in Arctic Summer Warming, Science, 310, 657-660, 2005.

Christensen, T. R., Jonasson, S., Callaghan, T. V., and Havström, M.: Spatial variaion in high-latitude methane flux alon a transect acorss Siberian and European tundra environments, J. Geophys. Res., 100(D10), 21 035-21 045, 1995.

Christensen, T. R., Friborg, T., Sommerkorn, M., Kaplan, J., Illeris, L., Soegaard, H., Nordstroem, C., and Jonasson, S.: Trace gas exchange in a high-arctic valley 1 . Variations in $\mathrm{CO}_{2}$ and $\mathrm{CH}_{4}$ flux between tundra vegetation types, Global Biogeoch. Cy., 14(3), 701-713, 2000.

Christensen, T. R., Ekberg, A., Ström, L., Mastepanov, M., Panikov, N., Oquist, M., Svensson, B. H., Nykänen, H., Martikainen, P. J., and Oskarsson, H.: Factors controlling large scale variations in methane emissions from wetlands, Geophys. Res. Lett., 30(7), 1414, doi:10.1029/2002GL016848, 2003.

Christensen, T. R., Johansson, T., Åkerman, H. J., Mastepanov, M., Malmer, N., Friborg, T., Crill, P., and Svensson, B. H.: Thawing sub-arctic permafrost, Geophys. Res. Lett., 31, L04501, doi:10.1029/2003GL018680, 2004.

Collatz, G., Ribas-Carbo, M., and Berry, J.: Coupled photosynthesisstomatal conductance model for leaves of C4 plants, Aust. J. Plant Physiol., 19, 519-538, 1992.
Corradi, C., Kolle, O., Walter, K., Zimov, S. A., and Schulze, E.-D.: Carbon dioxide and methane exchange of a north-east Siberian tussock tundra, Glob. Change Biol., 11, 1910-1925, doi:10.1111/j.1365-2486.2005.01023.x, 2005.

Dolman, A. J., Maximov, T. C., Moors, E. J., Maximov, A. P., Elbers, J. A., Kononov, A. V., Waterloo, M. J., and van der Molen, M. K.: Net ecosystem exchange of carbon dioxide and water of Far Eastern Siberian Larch (Larix dahurica) on permafrost, Biogeosciences, 1, 133-146, 2004, http://www.biogeosciences.net/1/133/2004/.

Esper, J. and Schweingruber, F. H.: Large-scale treeline changes recorded in Siberia, Geophys. Res. Lett., 31, L06202, doi:10.1029/2003GL019178, 2004.

Fahnestock, J. T., Jones, M. H., Brooks, P. D., Walker, D. A., and Welker, J. M.: Winter and early spring $\mathrm{CO}_{2}$ efflux from tundra communities of northern Alaska, J. Geophys. Res., 103(D22), 29 023-29 027, 1998.

Farquhar, G., von Caemmener, S., and Berry, J.: A biochemical model of photosynthesis $\mathrm{CO}_{2}$ fixation in leaves of $\mathrm{C} 3$ species, Planta, 149, 78-90, 1980.

Forster, P., Ramaswamy, V., Artaxo, P., Berntsen, T., Betts, R., Fahey, D. W., Haywood, J., Lean, J., Lowe, D. C., Myhre, G., Nganga, J., Prinn, R., Raga, G., Schulz, M., and van Dorland R.: Changes in Atmospheric Constituents and in Radiative Forcing, in: Climate Change 2007: The Physical Science Basis, Contribution of Working Group I to the Fourth Assessment Report of the Intergovernmental Panel on Climate Change, edited by: Solomon, S., Qin, D., Manning, M., Chen, Z., Marquis, M., Averyt, K. B., Tignor, M., and Miller, H. L., Cambridge University Press, Cambridge, United Kingdom and New York, NY, USA, 2007.

French, H. M.: The Periglacial Environment, Longman, New York, 341 pp., 1996.

Friborg, T., Christensen, T. R., Hansen, B. U., Nordstroem, C., and Soegaard, H.: Trace gas exchange in a high-arctic valley 2 . Landscape $\mathrm{CH}_{4}$ fluxes measured and modelled using eddy correlation data, Global Biogeochem. Cy., 14(3), 75-723, 2000

Frolking, S., Roulet, N., and Fuglestvedt, J.: How northern peatlands influence the Earth's radiative budget: Sustained methane emission versus sustained carbon sequestration, J. Geophys. Res., 111, G01008, doi:10.1029/2005JG000091, 2006.

Gavrilov, A. V., Romanovskii, N. N., Hubberten, H.-W., and Romanovskii, V. E.: Distribution of islands - ice complex remnants on the East Siberian Arctic shelf, Earth Cryosphere, 7, 18-32, 2003.

Goulden, M. L., Munger, J. W., Fan, S. -M., Daube, B. C., and Wofsy, S. C.: Measurements of carbon sequestration by longterm eddy covariance: methods and a critical evaluation of accuracy, Glob. Change Biol., 2, 169-182, 1996.

Granberg, G., Grip, H., Lofvenius, M. O., Sundh, I., Svensson, B. H., and Nillson, M.: A simple model for simulation of water content, soil frost, and soil temperatures in boreal mixed mires, Water Resour. Res., 35(12), 3771-3782, 1999.

Heikkinen, J. E. P., Elsakov, V., and Martikainen, P. J.: Carbon dioxide and methane dynamics and annual carbon balance in tundra wetland in NE Europe, Russia, Global Biogeochem. Cy., 16(4), 1115, doi:10.1029/2002GB001930, 2002.

Heikkinen, J. E. P., Virtanen, T., Huttunen, J. T., Elsakov, V., and Martikainen P. J.: Carbon balance in East 
European tundra, Global Biogeochem. Cy., 18, GB1023, doi:10.1029/2003GB002054, 2004.

Hinzman, L. D., Bettez, N.D., Bolton, W.R., Chapin, F. S., et al.: Evidence and Implications of Recent Climate Change in Northern Alaska and Other Arctic Regions, Clim. Change, 72, 251298, 2007.

Hobbie, J. E., Kwiatkowski, B. L., Rastetter, E. B., Walker, D. A., and McKane, R. B.: Carbon cycling in the Kuparuk basin: Plant production, carbon storage, and sensitivity to future changes, J. Geophys. Res., 103(D22), 29 065-29 073, 1998.

Hobbie, S. E., Schimel, J. P., Trumbore, S. E., and Randerson, J. E.: Controls over carbon storage and turnover in high-latitude soils, Global Biogeochem. Cy., 6(1), 196-210, 2000.

IPCC: Third Assessment Report, Climate Change 2001, Cambridge Univ. Press, Cambridge, UK, 2001.

Jia, G. J., Epstein, H. E., and Walker, D. A.: Greening of arctic Alaska, 1981-2001, Geophys. Res. Lett., 30(20), 2067, doi:10.1029/2003GL018268, 2003.

King, J. Y., Reeburgh, W. S., and Regli, S. K.: Methane emission and transport by arctic sedges in Alaska: Results of a vegetation removal experiment, J. Geophys. Res., 103(D22), 29063 $29092,1998$.

Kutzbach, L., Wagner, D., and Pfeiffer, E.-M.: Effect of microrelief and vegetation on mehtane emission from wet polygonal tundra, Lena Delta, Northern Siberia, Biogeochem., 69, 341-362, 2004.

Kwon, H.-J., Oechel, W. C., Zulueta, R. C., and Hastings, S. J.: Effects of climate variability on carbon sequestration among adjacent wet sedge tundra and moist tussock tundra ecosystems, J. Geophys. Res., 111, G03014, doi:10.1029/2005JG000036, 2006.

Lafleur, P. M., Roulet, N. T., and Admiral, S. W.: Annual cycle of CO2 exhange at a bog peatland, J. Geophys. Res., 106, 30713081, 2001.

Lee, X., Fuentes, J. D., Staebler, R. M., Neumann, H. H.: Long-term observation of the atmospheric exchange of $\mathrm{CO}_{2}$ with a temperate deciduous forest in southern Ontario, Canada, J. Geophys. Res., 104(D13), 15975-15984, doi:10.1029/1999JD900227, 1999.

Lloyd, A. H., Rupp, T. S., Fastie, C. L., and Starfield, A. M.: Patterns and dynamics of treeline advance on the Seward Peninsula, Alaska, J. Geophys. Res., 107, 8161, (printed 108(D2)), doi:10.1029/2001JD000852, 2003.

Lynch, A. H., Slater, A. G., and Serreze, M.: The Alaskan Arctiv Frontal Zone: Forcing by orograhy, Coastal Contrast and the Boreal Forest, J. Climate, 14, 4351-4362, 2001.

McGuire, A. D., Sturm, M., and Chapin III, F. S.: Arctic Transitions in the Land-Atmosphere System (ATLAS): Background, objectives, results, and future directions, J. Geophys. Res., 108(D2), 8166, doi:10.1029/2002JD002367, 2003.

Moore, T. R. and Roulet, N. T.: Methane flux: Water table relations in northern wetlands, Geophys. Res. Lett., 20, 587-590, 1993.

Morrissey, L. A. and Livingston, G. P.: Methane emissions from Alaska arctic tundra: An assessment of local spatial variability, J. Geophys. Res., 97(D15), 16 661-16 670, 1992.

Nakai, T., van der Molen, M. K., Gash, J. H. C., and Kodama, Y.: Correction of sonic anemometer angle of attack errors, Agric. For. Meteorol., 136, 19-30, 2006.

Oberbauer, S. F., Starr, G., and Pop, E. W.: Effects of extended growing season and soil warming on carbon dioxide and methane exchange of tussoch tundra in Alaska, J. Geophys. Res.,
103(D22), 29 075-29 082, 1998.

Oberlander, E. A., Brenninkmeijer, C. A. M., Crutzen, P. J., Elansky, N. F., Golitsyn, G. S., Granberg, I. G., Scharffe, D. H., Hofmann, R., Belokov, I. B., Paretzke, H. G., and van Verthoven, P. F. J.: Trace gas measurements along the Trans-Siberian railroad: The TROICA 5 expedition, J. Geophys. Res., 107(D14), 4206, doi:10.1029/2001JD000953, 2002.

Panikov, N. S. and Sizova, M. V.: Growth kinetics of microorganisms isolated from Alaskan soil and permafrost in solid media frozen down to $-35^{\circ} \mathrm{C}$, FEMS Microbiology Ecology, 59(2), 500-512, doi:10.1111/j.1574-6941.2006.00210.x, 2007.

Petrescu, A. M. R., van Huissteden, J., M. Jackowicz-Korczynski, M. Yurova, A., Christensen, T. R., Crill, P. M., and Maximov, T. C.: Modelling $\mathrm{CH}_{4}$ emissions from arctic wetlands: effects of hydrological parameterization, Biogeosciences Discuss., 4, 3195-3227, 2007, http://www.biogeosciences-discuss.net/4/3195/2007/.

Post, W. M., Emanuel, W. R., Zinke, P. J., and Stangenberger, A. G.: Soil carbon pools and world life zones, Nature, 298, 156159, 1982.

Raghoebarsing, A. A., Smolders, A. J. P., Schmid, M. C., Rijpstra, W. I. C., Wolters-Arts, M., Derksen, J., Jetten, M. S. M., Schouten, S., Sinninghe-Damsté, J. S., Lamers, L. P. M., Roelofs, J. G. M., op den Camp, H. J. M., and Strous, M.: Methanotrophic symbionts provide carbon for photosynthesis in peat bogs, Nature, 436, 1153-1156, doi:10.1038/nature03802, 2005.

Rivkina, E. M., Friedmann, E. I., McKay, C. P., and Gilichinsky, D. A.: Metabolic activity of permafrost bacteria below the freezing point, Appl. Environ. Microbiol., 66(8), 3230-3233, 2000.

Rivkina, E. M., Shcherbakova, V., Laurinavichius, K., Petrovskaya, L., Krivushin, K., Kraev, G., Pecheritsina, S., and Gilichinsky, D. A.: Biogeochemistry of methane and methanogenic archaea in permafrost, FEMS Microbiology Ecology, 61(1), 1-15. doi:10.1111/j.1574-6941.2007.00315.x, 2007.

Schirrmeister, L., Siegert, C., Kuznetsova, T., Kuzmina, S., Andreev, A., Kienast, F., Meyer, H., and Bobrov, A.: Paleoenvironmental and paleoclimatic records from permafrost deposits in the Arctic region of Northern Siberia, Quatern. Int., 89, 97-118. 2002

Schlesinger, W. H.: Carbon sequestration in soils, Science, 284, 2095, 1999.

Serreze, M. C., Walsh, J. E., Chapin III, F. S., Osterkamp, T., Dyurgerov, M., Romanovsky, V., Oechel, W. C., Morison, J., Zhang, T., and Barry, R. G.: Observational evidence of recent change in the northern high-latitude environment, Climatic Change, 46, 159207, 2000 .

Soegaard, H., Nordstroem, C., Friborg, T., Hansen, B. U., Christensen, T. R., and Bay, C.: Trace gas exchange in a high-arctic valley 3: Integrating and scaling $\mathrm{CO}_{2}$ fluxes from canopy to landscape using flux data, footprint modelling and remote sensing, Global Biogeochem. Cy., 14(3), 725-744, 2000.

Stokstad, E.: Defrosting the Carbon freezer of the North, Science, 304, 1618-1620, 2004.

Turetsky, M. R., Wieder, R. K., and Vitt, D. H.: Boreal peatland C fuxes under varying permafrost regimes, Soil Biol. Biochem., 34, 907-912, 2002.

Treat, C. C., Bubier, J. L., Varner, R. K., and Crill, P.M.: Timescale dependence of environmental and plant-mediated controls on $\mathrm{CH}_{4}$ flux in a temperate fen, J. Geophys. Res., 112, G01014, 
doi:10.1029/2006JG000210, 2007.

Tsuzuyaki, S. Nakano, T., Kuniyoshi, S., and Fukuda, M.: Methane flux in grassy marshland near Kolyman River, north-eastern Siberia, Soil Biol. Biochem., 33, 1319-1423, 2001.

Turner, D. P., Ritts, W. D., Cohen, W. B., Gower, S. T., Running, S. W., Zhao M., Costa, M. H., Kirschbaum, A. A., Ham, J. M., Saleska, S. R., and Ahl, D. E.: Evaluation of MODIS NPP and GPP products across multiple biomes, Remote Sens. Environ., 102, 282-292, 2006.

van Huissteden, J. and van den Bos, R. M.: Modelling the effect of water-table management on $\mathrm{CO}_{2}$ and $\mathrm{CH}_{4}$ fluxes from peat soils, in: Human influence on carbon fluxes in coastal peatlands; process analysis, quantification and prediction, edited by: van den Bos, R.M., Thesis, Vrije Universiteit, 67-90, 2003.

van Huissteden, J. C.: Methane emission from northern wetlands in Europe during Oxygen Isotope Stage 3, Quat. Sci. Rev., 23, 1989-2005, 2004.

van Huissteden, J. C., Maximov, T. C., and Dolman, A. J.: High methane flux from an arctic floodplain (Indigirka lowlands, eastern Siberia), J. Geophys. Res., 110, G02002, doi:10.1029/2005JG000010, 2005.

van der Molen, M. K., Gash, J. H. C., and Elbers, J. A.: Sonic anemometer cosine response and flux measurement: II The effect of introducing an angle of attack dependent calibration, Agric. For. Meteorol., 122, 95-109, http://dx.doi.org/10.1016/j. agrformet.2003.09.003, 2004.

van der Molen, M. K., Zeeman, M. J., Lebis, J., and Dolman, A. J.: EClog: A handheld eddy covariance logging system. Computers and Electronics in Agriculture, 51(1-2), 110-114, http://dx.doi. org/10.1016/j.compag.2005.12.002, 2006.

Verville, J. H., Hobbie, S. E., Chapin III, F. S., and Hooper, D. U.: Response of tundra $\mathrm{CH}_{4}$ and $\mathrm{CO}_{2}$ flux to manipulation of temperature and vegetation, Biogeochemistry, 41, 215-235, 1998.

Wagner, D., Lipski, A., Embacher, A., and Gattinger, A.: Methane fluxes in permafrost habitats of the Lena Delta: effects of microbial community structure and organic matter quality, Env. Microbiol., 7, 1582-1592, 2005.
Wagner, D., Gattinger, A., Embacher, A., Pfeiffer, E.-M., Schloter, M., and Lipski, A.: Methanogenic activity and biomass in Holocene Permafrost deposits of the Lena Delta, Siberian Arctic and Its implication for the global methane budget, Glob. Change Biol., 13, 1-11, doi:10.111/j.1365-2486.2006.01331.x, 2007.

Walter, B. P, Heimann, M., Shannon, R. D., and White, J. R.: A process-based model to derive methane emissions from natural wetlands, Geophys. Res. Lett., 23(25), 3731-3734, 1996.

Walter, B. P.: A process-based, climate-sensitive model to derive methane emissions from natural wetlands: Application to five wetland sites, sensitivity to model parameters, and climate, Global Biogeochem. Cy., 14, 745-765, 2000.

Wilmking, M., Harden, J., and Tape, K.: Effect of tree line advance on carbon storage in NW Alaska, J. Geophys. Res., 111, G02023, doi:10.1029/2005JG000074, 2006.

Wille, C., Kutzbach, L., Sachs, T., Wagner, D., and Pfeiffer, E.-M.: Methane Emission from Siberian arctic polygonal Tundra: Eddy Covariance Measurements and Modeling, in press, 2007.

Yang, P. C., Black, T. A., Neumann, H. H., Novak, M. D., Blanken, P. D.: Spatial and temporal variability of $\mathrm{CO} 2$ concentration and flux in a boreal aspen forest, J. Geophys. Res., 104(D22), 27653 27 662, doi:10.1029/1999JD900295, 1999.

Yershov, E. D.: General Geocryology, Cambridge Univ. Press, New York, 580 pp., 1998.

Yurova, A., Wolf, A., Sagerfors, J., and Nilsson, M.: Variations in net ecosystem exchange of carbon dioxide in a boreal mire: modelling mechanisms linked to water table position, J. Geophys. Res., Biogeosciences, 112, G02025, doi:10.1029/2006JG000342, 2007.

Zimov, S. A., Voropaev, Y. V., Semiletov, I. P., Davidov, S. P., Prosiannikov, S. F., Chapin III, F. S., Chapin, M. C., Trumbore, S., and Tyler, S.: North Siberian lakes: A methane source fueled by Pleistocene carbon, Science, 277, 800-802, 1997.

Zimov, S. A., Schuur, E. A. G., and Chapin, F.S .: Permafrost and the global carbon budget, Science, 312, 1612-1613, 2006. 